\title{
Characterizing Consecutive Flooding Events after the 2017 Mt. Salto Wildfires (Southern Italy): Hazard and Emergency Management Implications
}

\author{
Giuseppe Esposito ${ }^{1, *(1)}$, Antonio Parodi ${ }^{2}$, Martina Lagasio ${ }^{2}\left(\right.$, Rocco Masi ${ }^{2}$, \\ Giovanni Nanni ${ }^{3}$, Filiberto Russo ${ }^{3}$, Stefano Alfano ${ }^{3}$ and Gaetano Giannatiempo ${ }^{3}$ \\ 1 Consiglio Nazionale delle Ricerche, Istituto di Ricerca per la Protezione Idrogeologica (CNR-IRPI), \\ via Cavour 4/6, 87036 Rende (CS), Italy \\ 2 Fondazione CIMA, via Magliotto 2, 17100 Savona, Italy; antonio.parodi@cimafoundation.org (A.P.); \\ martina.lagasio@cimafoundation.org (M.L.); rocco.masi@cimafoundation.org (R.M.) \\ 3 Direzione Regionale Vigili del Fuoco Campania, via Del Sole 10, 80138 Napoli, Italy; \\ giovanni.nanni@vigilfuoco.it (G.N.); filiberto.russo@vigilfuoco.it (F.R.); stefano.alfano@vigilfuoco.it (S.A.); \\ gaetano.giannatiempo@vigilfuoco.it (G.G.) \\ * Correspondence: giuseppe.esposito@irpi.cnr.it; Tel.: +39-0984-841-432
}

Received: 16 October 2019; Accepted: 11 December 2019; Published: 17 December 2019

\begin{abstract}
Every summer, wildfires affect thousands of steep watersheds in Italy, causing the partial or complete destruction of vegetation, and changes in soil hydraulic properties. Such effects alter the hydrologic response of watersheds, increasing post-fire debris and sediment-laden flow hazard. This study characterizes the most relevant predisposing and triggering factors for a sequence of four post-fire flooding events, which, in the late summer-autumn of 2017, affected Montoro village in southern Italy. This research work consists of a fire severity assessment based on multispectral satellite images, characterization of meteorological systems and related flood-triggering rainfall, and provides an overview of the damage that occurred in the repeatedly affected urban area using crowdsourced data. The research findings demonstrate that the analyzed area burned with moderate-high $(64.4 \%)$ and low severity $(35.6 \%)$ levels. All the flooding events were triggered by rainfall evaluated as non-extreme, but with relevant peak intensities $\left(\mathrm{I}_{10}\right.$ and $\mathrm{I}_{30}$ ), associated with the first convective storms impacting the burned watersheds. The crowdsourced data highlight the fact that roads and buildings on footslopes were inundated by mud and debris transported by rapid flows. The study identifies a clear relationship between wildfires and flooding processes and provides useful information for hazard assessment and emergency management operations.
\end{abstract}

Keywords: andosols; fire severity; rainstorm; post-fire flooding response; remote sensing; VGI data; emergency management

\section{Introduction}

Wildfires represent one of the most widespread hazards in Mediterranean forest ecosystems. The effects of the ongoing climate change promote long-lasting periods of drought and heat waves, with favorable conditions for the ignition and propagation of severe fires $[1,2]$. Pronounced vegetation and soil moisture reduction during summer droughts can increase the likelihood of high-severity crown fire, especially with high winds [3]. Fire intensity, together with fire residence time (heating duration), vegetation properties, topography, substrate, and climate control the loss or decomposition of aboveground and belowground organic matter [4], meaning that each fire can burn with different severity levels. In order to perform a fire severity assessment, both field and remote sensing approaches can be used. Generally, extensive field observations can be made for accessible and limited burned 
areas, or in specific sites, to calibrate/validate remote sensing results $[5,6]$. Conversely, for larger and more inaccessible fires, remote sensing and GIS can greatly improve the speed, precision, and accuracy of post-fire mapping efforts [6]. Spaceborne and airborne multispectral sensors detect changes in the composition and moisture of aboveground vegetation and char/ash deposition by measuring modifications of the recorded electromagnetic spectrum, with respect to pre-fire conditions [7-9]. In this way, a wide set of spectral indices were developed to map burned scars and characterize fire severity. A consistent description of the most used indices was provided by Mallinis et al. [8]. As reported by these authors, indices considering Near Infrared (NIR) and Shortwave Infrared (SWIR) spectral regions are widely employed because they are less sensitive to atmospheric contamination, while they quantify vegetation removal, charcoal deposition, and reduction of the canopy moisture and canopy shadow, which lead to a reduced NIR and higher SWIR post-fire reflectance, respectively, compared to healthy vegetation. One of the most used indices exploiting these bands is the differenced Normalized Burned Ratio index (dNBR), based on the subtraction of the $\mathrm{NBR}_{\text {post-fire }}$ from the $\mathrm{NBR}_{\text {pre-fire }}[5,10]$. The $\mathrm{dNBR}$ data are grouped according to threshold-based classification models (e.g., [5]) to represent different fire severity levels. This index has been successfully tested worldwide, as well as in the Mediterranean area, showing a fair accuracy with respect to field measurements of fire severity [8,11-18].

A fire severity assessment is essential for the analysis of post-fire flooding events, given that a strong correlation between fire severity and changes in the hydrological response of burned watersheds has been ascertained in many regions of the world (e.g., [19-22]). Wildfires are able to reduce the infiltration capacity of soils by inducing or enhancing, for example, soil water repellency (SWR) [23-27]. A direct consequence of SWR, or of the eventual surface sealing by ash, fine soil particles, and rainsplash, is the enhanced runoff during the first high-intensity rainstorms following wildfires. This is crucial for the triggering of debris and sediment-laden flows. As reported by Parise and Cannon [28], the runoff-dominated erosion by surface overland flow is the principal mechanism controlling the initiation of debris flow processes in burned watersheds. This was also ascertained in the major Montecito debris flow event that occurred in the winter of 2018 in California (USA), causing 23 fatalities, at least 167 injuries, and 408 damaged homes [29,30]. Besides high-magnitude events like this, it is worth underlining that the spectrum of post-wildfire hydrologic and sedimentologic responses also includes less-severe events or no response, as documented in different locations across the globe [31].

The general interest of the scientific community towards geo-hydrological processes occurring in fire-affected areas is increasing worldwide, and significant efforts are being made to develop risk mitigation activities [32-35]. In Italy, post-fire geo-hydrological processes have been mostly documented in the central and southern regions [36-42], with some cases in the north $[43,44]$. In spite of a considerable frequency of rainstorms that each year impact on fire-affected mountainous areas, the number of documented post-fire events is limited. This is not due to the lack of post-fire processes, but scarce interest by the scientific community. As a consequence, knowledge about meteorological systems, triggering rainfall, relationships between fire severity topography and hydrological response of watersheds, and magnitude of flow processes is still poor. For this reason, there is a concrete need to collect these types of data in post-fire settings occurring in Italy.

In this paper, we document four consecutive post-fire flooding events that in 2017 hit the village of Montoro in southern Italy (Figure 1). Note that with the term "flooding", we refer to the broad spectrum of flow processes recognized in post-fire settings worldwide, mainly consisting in the transition from surface water flow through to hyperconcentrated flow to debris flow [45]. The principal research aim is to characterize the most relevant predisposing and triggering factors of the fire-flood sequence, reporting data about fire severity, meteorological systems, and related flood-triggering rainfall, and an overview of the damage that occurred in the repeatedly affected urban area using crowdsourced data. Because of the rough morphology, it was not possible to collect field data related to soil properties and geomorphic changes. Outcomes of this study thus describe the general conditions that led to the occurrence of repeated post-fire flooding responses in a span of few weeks in the same area. A sequence of flooding events after wildfires in Italy has not been documented as yet. All findings are 
accounted for in a general discussion focused on the possible relationships between the analyzed factors, and on the potential use of meteorological data in early warning systems.

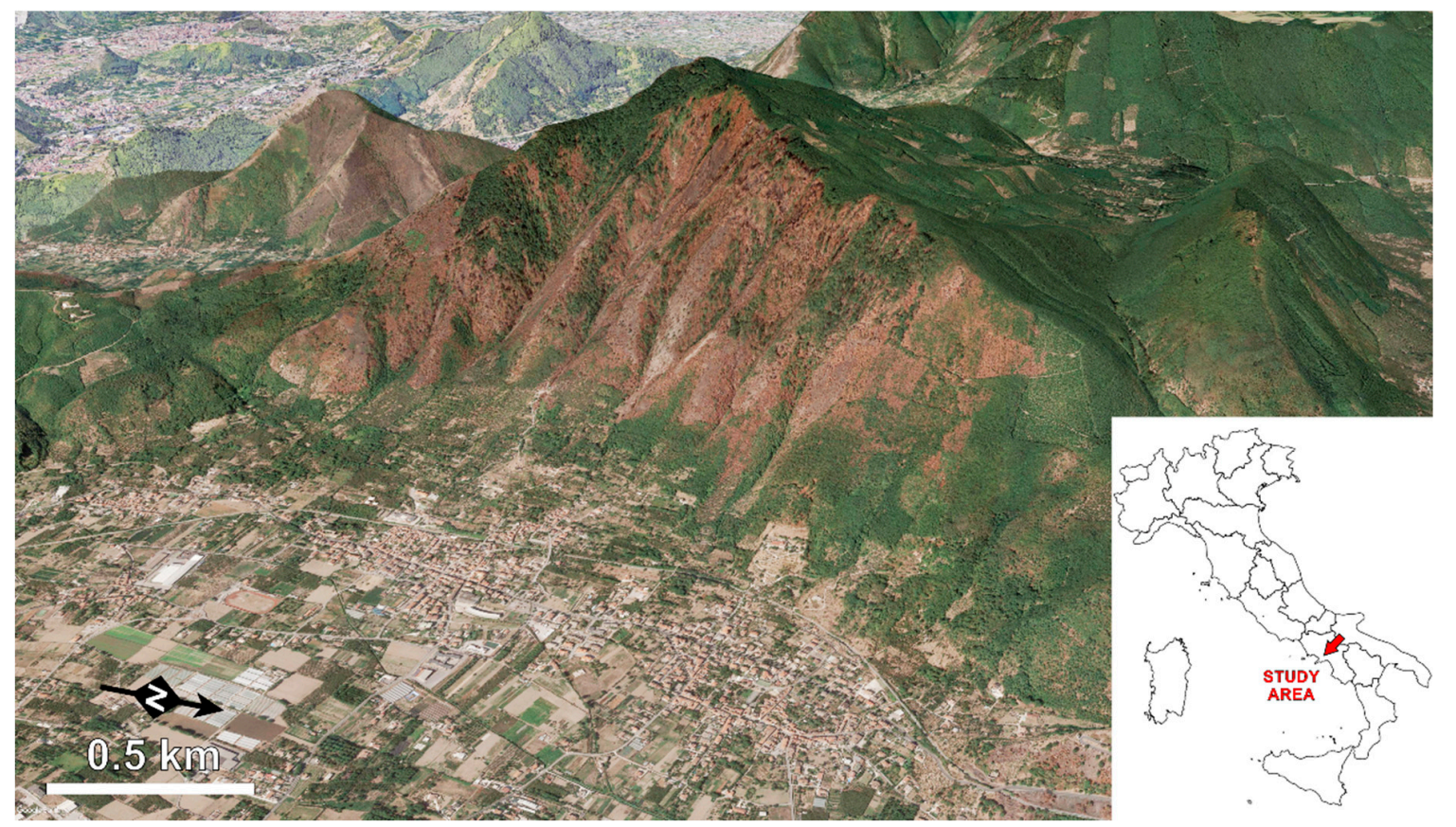

Figure 1. Google Earth RGB image acquired on 24 August 2017, showing the Mt. Salto area and the village of Montoro located on the footslope. The reddish tones identify the east-oriented hillslope affected by wildfires in July 2017. The inset map shows location of the study area in southern Italy.

\section{Study Area}

Mt. Salto is a carbonate massif reaching a maximum elevation of $955.7 \mathrm{~m}$ above sea level (Figure 1). The bedrock is formed by Mesozoic limestone and dolomite rocks that since the Late Quaternary have been repeatedly mantled by pyroclastic airfall deposits, as a result of the explosive activity of the Somma-Vesuvius volcanic complex, located $25 \mathrm{~km}$ from the study site [46-48]. The thickness of the pyroclastic cover varies according to topography, from half a meter up to 3-4 $\mathrm{m}$. The volcaniclastic deposits are interbedded with pedogenized horizons that are classified as andosols [49], including the current topsoil. This type of soil is characterized by relatively low cohesion under dry conditions $[50,51]$ and high erodibility when slope-stabilizing vegetation is absent [52]. The footslopeof Mt. Salto is formed by a talus consisting of a mix of reworked volcaniclastic deposits and carbonate debris derived from erosion and mass wasting processes that occurred in the past centuries. In 1998, for example, a shallow landslide evolving into debris flow downstream mobilized the volcaniclastic deposits after prolonged rainfall. A brief inventory including this and other historical geo-hydrological processes that occurred in the area was published by Mobilia et al. [53]. Note that mass movements, which mobilize pyroclastic covers into shallow landslides (subsequently evolving into debris flow) are substantially different from post-fire processes discussed in the current study, both with respect to triggering mechanisms and displaced volumes. As reported by Napolitano et al. [54], for example, the triggering of initial slope instabilities is highly dependent on antecedent soil moisture conditions and seasonal precipitation regime. The displaced volumes can be very high, reaching up to hundreds of thousands cubic meters [55].

The east-oriented hillslope of Mt. Salto analyzed in this study consists of 10 watersheds (Figure 2), whose morphometric characteristics are summarized in Table 1. Most of these watersheds and related main channels are characterized by an overall steepness, as evidenced by slopes and relief ratios. At the outlets, slopes of the main channels decrease abruptly, some by even more than $20^{\circ}$. The drainage 
network on the footslope has been greatly modified by human intervention, including culverts and bridges, and some channels have become roads that connect urban centers.

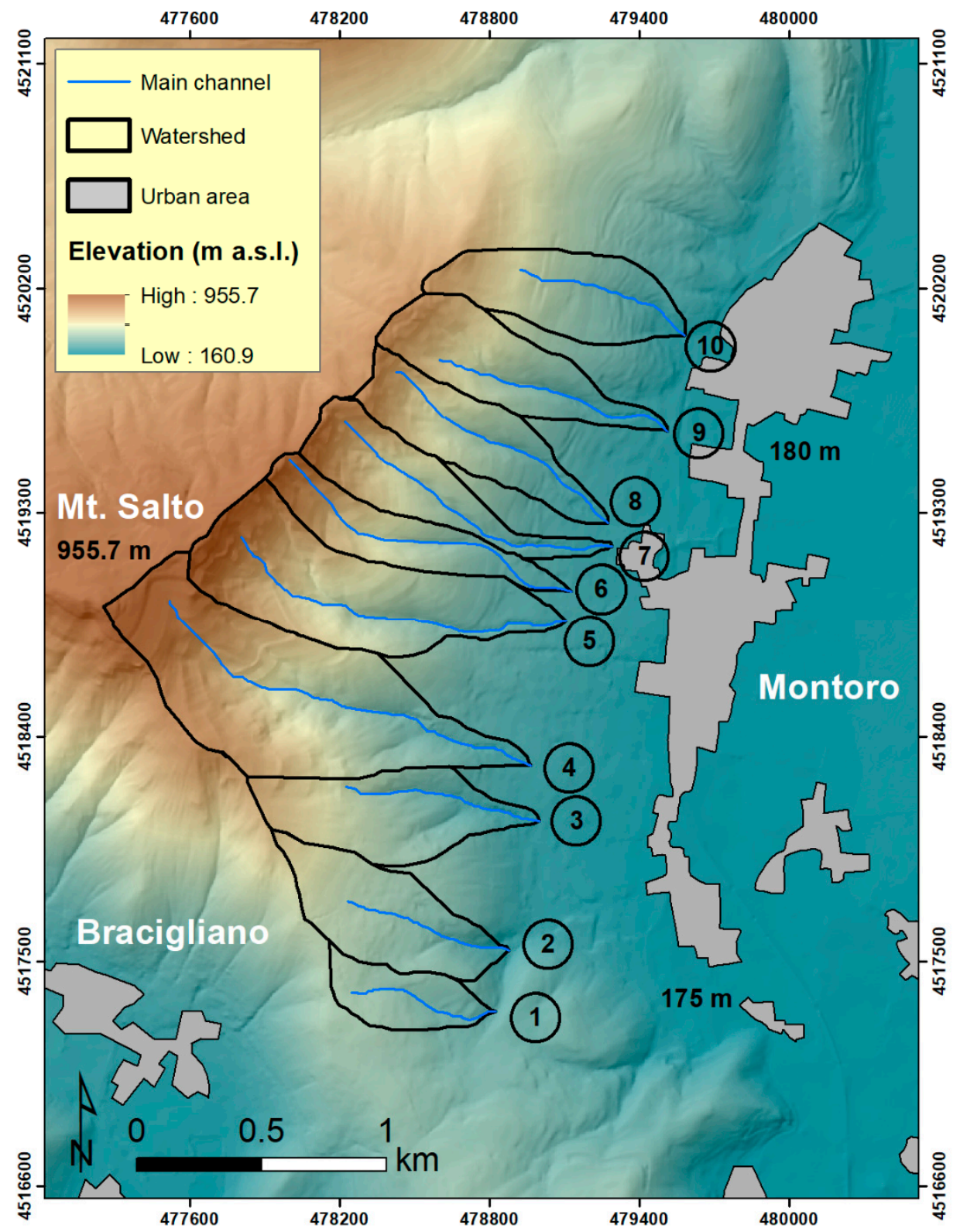

Figure 2. Topography of the study area. The numbers identify the analyzed watersheds in Table 1.

Table 1. Morphometric properties of the analyzed watersheds.

\begin{tabular}{ccccccccccc}
\hline Watershed & $\mathbf{1}$ & $\mathbf{2}$ & $\mathbf{3}$ & $\mathbf{4}$ & $\mathbf{5}$ & $\mathbf{6}$ & $\mathbf{7}$ & $\mathbf{8}$ & $\mathbf{9}$ & $\mathbf{1 0}$ \\
\hline Area (ha) & 13 & 28 & 30 & 70 & 50 & 22 & 23 & 25 & 26 & 29 \\
Perimeter $(\mathrm{km})$ & 1.9 & 2.5 & 2.9 & 4.3 & 3.6 & 2.9 & 3.0 & 2.8 & 2.8 & 2.7 \\
Average slope $\left({ }^{\circ}\right)$ & 14 & 20 & 26 & 31 & 35 & 32 & 35 & 32 & 32 & 27 \\
Relief $(\mathrm{m})$ & 167 & 419 & 539 & 725 & 705 & 657 & 663.5 & 580 & 582 & 532 \\
Main channel length $(\mathrm{km})$ & 0.6 & 0.7 & 0.8 & 1.7 & 1.5 & 1.3 & 1.3 & 1.1 & 1.0 & 0.7 \\
Main channel average slope $\left(^{\circ}\right)$ & 13 & 19 & 21 & 23 & 26 & 26 & 26 & 27 & 25 & 23 \\
Main channel slope at outlet $\left({ }^{\circ}\right)$ & 7 & 5 & 4 & 5 & 6 & 9 & 2 & 4 & 3 & 6 \\
Relief ratio & 0.27 & 0.61 & 0.66 & 0.43 & 0.48 & 0.49 & 0.53 & 0.54 & 0.59 & 0.72 \\
Slope ratio & 0.93 & 0.95 & 0.81 & 0.74 & 0.74 & 0.81 & 0.74 & 0.84 & 0.78 & 0.85 \\
\hline
\end{tabular}


The climate in the area is of Mediterranean type with hot, dry summers and moderately cool, rainy winters. The annual average rainfall is in the order of $1200 \mathrm{~mm} /$ year, with a concentration of maximum daily precipitation in the late summer-autumn period. According to Longobardi et al. [56], this concentration coincides with the highest frequency of geo-hydrological events that in the 1951-2014 time period affected Montoro and other neighboring villages. The climatic conditions allow a well-developed vegetation cover to be formed by Mediterranean shrubs mixed with chestnut and oak trees.

\section{Materials and Methods}

\subsection{Fire Severity Assessment}

Fire severity assessment was carried out by using satellite data acquired by the Sentinel-2 Multispectral Sensor Instrument (MSI) of the European Spatial Agency (ESA). This sensor measures the Earth's reflected radiance over 13 spectral bands spanning from visible and NIR to SWIR bands, at different spatial resolutions [57]. Taking into account the approach of Garcia-Llamasa et al. [11], the available cloud-free pre-and post-fire images closest to the dates of the fires were selected. This prevents phenological changes in the vegetation, and enables comparison among products. Specifically, since the fires affected the study area in the period from 5 July to 12 July 2017, images referred to 18 May 2017 (pre-event) and 17 July 2017 (post-event) were considered as the best ones for the analysis. They were downloaded from the Sentinel's Scientific DataHub (https://scihub.copernicus.eu/), and corresponded to Level-1C products delivered after radiometric and geometric corrections, including orthorectification and spatial registration on a global reference system (ortho-images in UTM/WGS84 projection) with sub-pixel accuracy, and the top-of-atmosphere reflectance calculation [58]. The downloaded images were then processed using the Sen2Cor plugin, available on the Sentinel-2 Toolbox contained in the software SNAP 6.0 (ESA, Paris, France), in order to obtain the ground reflectance (Bottom-Of-Atmosphere) for each pixel.

To identify the burned area and characterize fire severity, the dNBR spectral index $[5,10]$ was calculated by means of the following equations:

$$
\begin{gathered}
\mathrm{NBR}=\frac{\mathrm{NIR}-\mathrm{SWIR}}{\mathrm{NIR}+\mathrm{SWIR}} \\
\mathrm{dNBR}=\mathrm{NBR}_{\text {pre-fire }}-\mathrm{NBR}_{\text {post-fire }}
\end{gathered}
$$

In accordance with the findings of Huang et al. [59] concerning the most suitable bands to detect burned areas and distinguishing fire effects using Sentinel-2 data, the narrow NIR band (B8a) and longer SWIR band (B12) were used. Both bands are characterized by a pixel spatial resolution of $20 \mathrm{~m}$. The $\mathrm{dNBR}$ data were then converted into fire severity classes by applying the general thresholds proposed by Key and Benson [5]: unburned $(<0.1)$; low severity (0.1-0.269); moderate severity $(0.269-0.659)$; high severity $(>0.659)$.

\subsection{Storm-Related Meteorological Observations}

Meteorological systems impacting the study area after wildfires and generating rainfall conditions to trigger the analyzed flooding processes were characterized by means of satellite and radar observations, as well as by providing synoptic backgrounds.

As satellite data, we used those acquired by the SEVIRI sensor mounted on the Meteosat Second Generation (MSG) platform, in the thermic infrared band $(10.8 \mu \mathrm{m})$.

Radar data were acquired by the C-band sensors of the Italian Radar Network managed by the Department of Civil Protection [60].

Synoptic analyses were carried out by considering the most advanced products of the fifth generation ECMWF atmospheric reanalysis of global climate, ERA5, characterized by a spatial resolution of about $30 \mathrm{~km}$, and a temporal resolution of $1 \mathrm{~h}$. 


\subsection{Rainfall Data}

Rainfall data used in this study were collected by a rain gauge of the Campania Region Civil Protection, located at $2 \mathrm{~km}$ from the Mt. Salto area (Figure 3), with a sampling rate of $10 \mathrm{~min}$. The acquired dataset covered the post-fire time period from 1 August to 30 November 2017. The maximum rainfall amount recorded in a time interval of $30 \mathrm{~min}$ was calculated for each rainy day, as a quantifiable metric recommended by Moody et al. [31] to characterize the rainfall regime associated with post-wildfire responses. Rainfall triggering the post-fire flooding processes were then characterized with an in-depth analysis, by evaluating the following metrics: total rainfall duration and amount; maximum amount cumulated in $30 \mathrm{~min}$ and related recurrence interval; maximum amount cumulated in $10 \mathrm{~min}$; maximum intensity reached in $30\left(\mathrm{I}_{30}\right)$ and $10\left(\mathrm{I}_{10}\right)$ minutes. The recurrence intervals were calculated by modeling the available annual maxima recorded at the selected rain gauge in the period of 2007-2018, according to the Gumbel statistical distribution.

\subsection{Evaluation of Flooding Impact Using Crowdsourced Data}

As reported by Esposito et al. [61], many studies have underlined the valuable use of web news and social media for flood mapping [62], streamflow estimation [63,64], damage assessment [65], and flood prediction [66,67]. Crowdsourced data and Volunteered Geographic Information (VGI) have also been used to develop road damage maps, representing a fundamental tool in disaster response operations [68]. According to Pennington et al. [69], the use of social media helps acquire detailed information about the impacts, remediation, and triggers at the time of the event, many of which could be otherwise unknown. In the light of this, the spatial extent and types of damage related to the analyzed post-fire flooding events were evaluated by collecting information published on news websites, or provided by eyewitnesses via social media. Information was selected manually by analyzing contents published on both websites and social pages of local news agencies, as well as by performing keywords-based searches on Google search engine and social networks. For each event, watersheds affected by flow responses were identified; photos and videos, together with information released by eyewitnesses in the interviews performed by reporters in the aftermath were used to infer the timing and type of flow processes. Ancillary information was provided by geologists of the Montoro municipality, who performed a series of fieldworks in the affected areas. A general analysis of the collected data allowed the reconstruction of the whole fire-flood sequence, highlighting differences and similarities between the events. Part of the collected information was summarized in a specific map realized in GIS environment.

\section{Results}

\subsection{Fire Severity}

The multi-temporal comparison between pre- and post-fire Sentinel-2 BOA reflectance images allowed us to identify the Mt. Salto area affected by fires, on both east and south-west sides (Figure 3). This study, however, was aimed at accounting for only effects on the eastern side, in the municipality of Montoro. Here, all the watersheds were partially burned with different severity levels. The histogram in Figure 4 provides results of the fire severity assessment executed for each watershed. The central watersheds, from 5 to 9, and watershed 3, were the most affected in terms of spatial extent of the burned surface. More than $70 \%$ of their areas was in fact hit by fires. In particular, watershed 7 ( $23 \mathrm{ha}$ ) was the worst damaged, with $92 \%$ (21.2 ha) of its surface burnt. Lateral watersheds (1, 2 and 10) were the less affected, with a percentage of burned area of about $40 \%$.

The statistics in Figure 4 highlight that moderate severity was the most widespread. In fact, out of a total of 221.4 ha of burnt surface, 24.1 ha resulted burned with low severity, 118.3 ha with moderate severity, and 79 ha with high severity. In summary, $64.4 \%$ of the fire-affected area was burned with a moderate-high severity, and 35.6\% with low severity. Watershed 5 (50 ha) was characterized by the largest surface burnt with moderate-high severity, corresponding to 32 ha out of a total burned surface 
of 43 ha. The largest surface burned with low severity was for watershed 4 ( 23 ha out of a total burned surface of $47 \mathrm{ha}$ ).

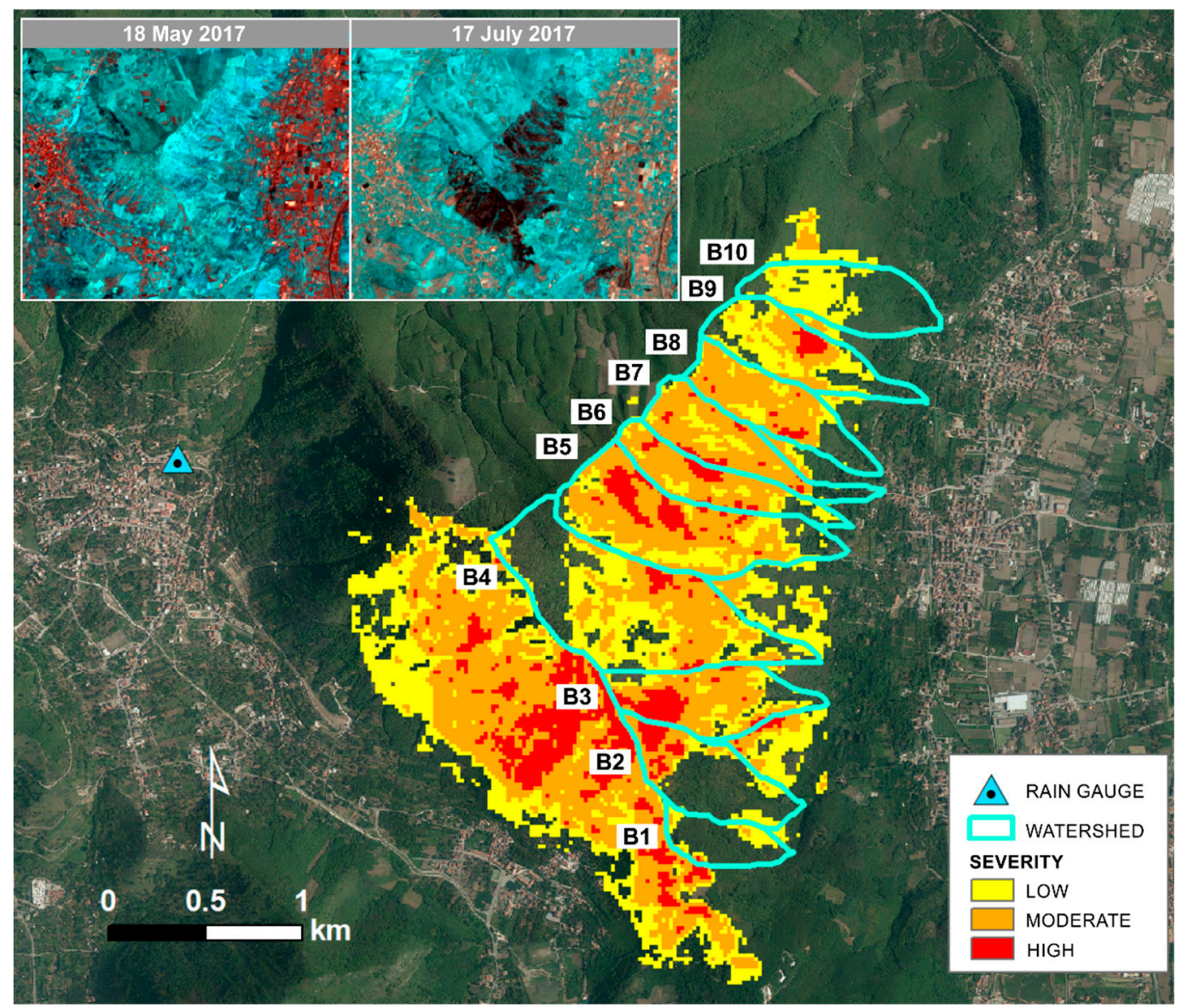

Figure 3. Fire severity map created using dNBR values. Pre- and post-fire false color composite images, shown in the inset, highlight the burned Mt. Salto area.

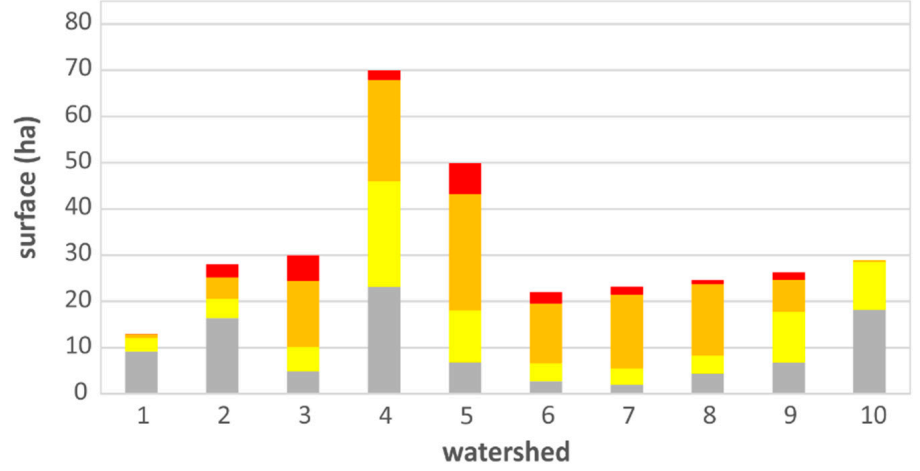

a HIGH SEVERITY MODERATE SEVERITY LOW SEVERITY UNBURNED

Figure 4. Amounts of watershed surface affected by different fire severity levels.

\subsection{Properties of Meteorological Systems and Flood-Triggering Rainfall}

After the wildfires of July 2017, the study area was hit by a series of rainstorms that started in the month of September. Those that occurred on 2 September 2017, 11 September 2017, 22 October 2017, and 6 November 2017 released sufficient rain to trigger post-fire flooding events.

Synoptic conditions related to the four events spanned from a weak baroclinic circulation to conditions characterized by large scale circulation patterns, typical of the autumn season (Figure 5). 
The $850 \mathrm{hPa}$ temperature and geopotential fields (Figure 5) suggest a significant advection of warm air from northern Africa for the two September cases studies, while the October and November ones do not show such pronounced characteristics. Correspondingly, the September events were characterized by definitely larger (1500-2000 J/kg) convective available potential energy (CAPE) and integrated water vapor content (30-35 mm) with respect to the October and November ones.

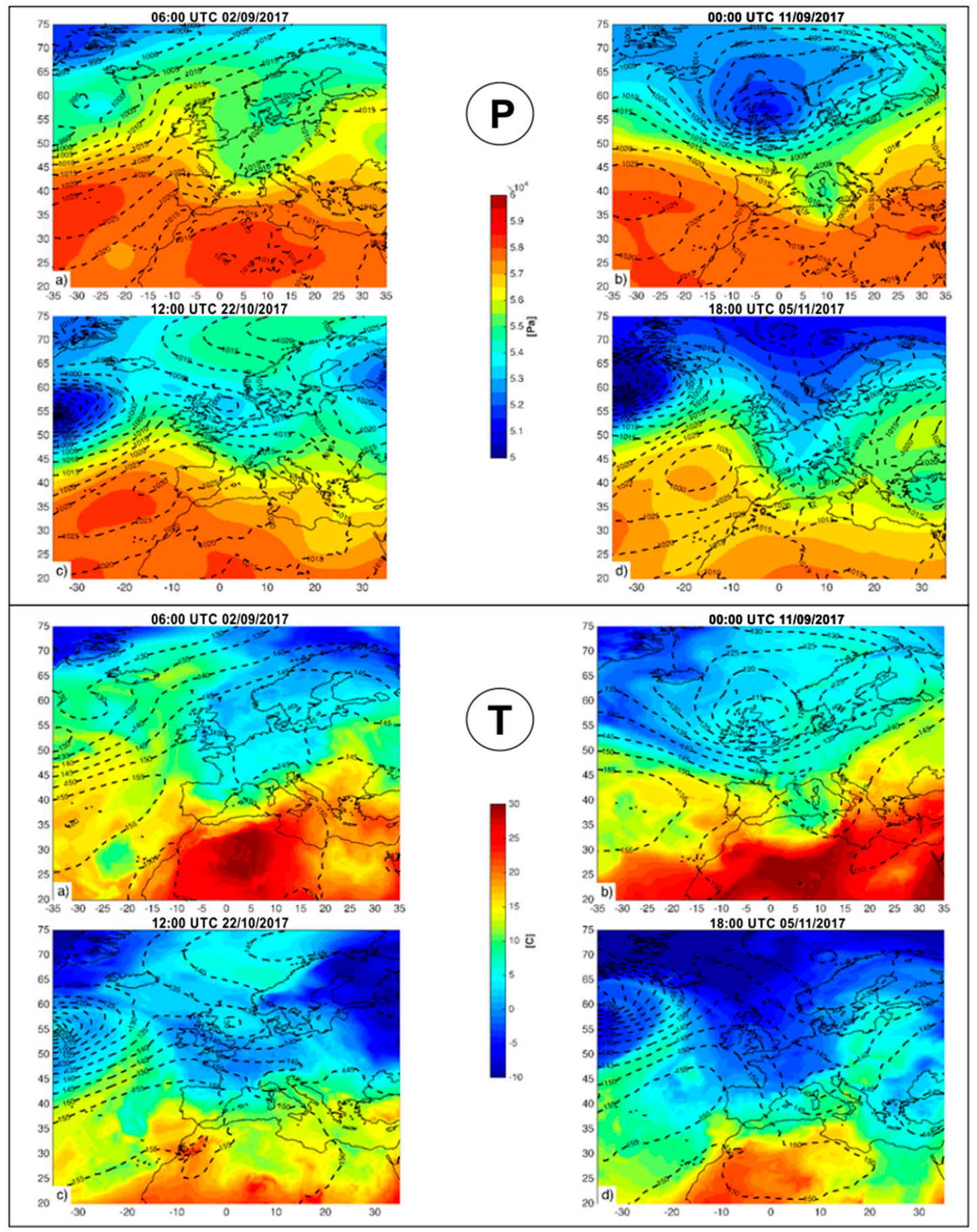

Figure 5. (P) $500 \mathrm{hPa}$ geopotential field and mean sea level pressure field at the onset of the respective rainfall periods (ERA 5 analysis data). (T) 850 temperature field and contour geopotential field at the onset of the respective rainfall periods (ERA 5 analysis data). 
A useful classification of intense precipitation events has been introduced by Molini et al. [70], who examined the duration, spatial extent, and large/small-scale triggering of events in a high-resolution precipitation dataset. An objective classification system for these events was developed, and two typologies were identified: Type I long-lived (duration $\mathrm{d} \geq 12 \mathrm{~h}$ ) and spatially distributed (more than AS $\left.=50 \times 50 \mathrm{~km}^{2}\right)$; Type II events brief and localized, having a shorter duration $(\mathrm{d}<12 \mathrm{~h})$ and a spatial extent smaller than AS. Although the analysis was restricted to Italy, these categories are considered as representative of flash flood-producing storms in the whole Mediterranean area. In a subsequent study, Molini et al. [71] explored the hypothesis that the two categories of precipitation events identified by Molini et al. [70] solely on the basis of area and duration of precipitation correspond to the two dynamical regimes of equilibrium and non-equilibrium convection. First equilibrium convection, where it is assumed that production of CAPE by large-scale processes is nearly balanced by its consumption by convective phenomena, and thus CAPE values stay small. In this case, the overall size, location, and intensity of the precipitating region are determined by the large-scale flow. In the second, non-equilibrium regime, a larger amount of CAPE is available, as a result of building up from large-scale processes over long time-scales, but the extent to which it produces convection and precipitation is restricted by the need for a trigger sufficient to overcome the convective inhibition energy (CIN). Since these events are typically driven by local orographic or surface-flux variability, they may be hard to predict, even if the large-scale meteorological situation is known. Satellite- and radar-based data highlighted in Appendix A reveal that all the flood-triggering rainstorms were associated with frontal convective systems characterized by different evolution times. Generally, the impact of these systems with the Mt. Salto study area lasted from one to six hours. Their temporal duration (below $12 \mathrm{~h}$ ), in association with medium to large CAPE values, hence suggest that these events belong to Type II events (brief and localized), corresponding to non-equilibrium conditions.

Data relating to the cloud top height reached considerable values in correspondence with the study area, whereas the vertical maximum intensity (VMI) radar reflectivity was not particularly high. As shown in Figure 6 and Table 2, for example, at the approximate flooding initiation times of the 11 September 2017 and 6 November 2017 events, the cloud top reached heights up to $12 \mathrm{~km}$, whereas the maximum VMI reflectivity was of $36 \mathrm{dBZ}$ (Table 2).

Analysis of rainfall data collected until 6 November 2017 (date of the last event) highlights that rainfall with highest $\mathrm{I}_{30}$ occurred in the same days of the flooding events (Figure 7), with values ranging from $16 \mathrm{~mm} / \mathrm{h}$ (2 September 2017) to $36 \mathrm{~mm} / \mathrm{h}$ (6 November 2017). Successive rainfall characterized by comparable $\mathrm{I}_{30}$ (e.g., November 30) did not result in flooding responses. Data shown in Figure 7 also indicate the occurrence of light inter-storm precipitations with $\mathrm{I}_{30}$ lesser than $5 \mathrm{~mm} / \mathrm{h}$.

In Table 2, metrics of the four flood-triggering rainfalls are shown. As a general observation, both duration and total amounts of such rainfalls are characterized by an increase over time. In the first two events, most of the rain occurred in $10 \mathrm{~min}$ and $30 \mathrm{~min}$, respectively. In the other two events, rainfall was less concentrated in time even if considerable pulses, corresponding to about half of the total amounts, were recorded within $30 \mathrm{~min}$. The recurrence intervals related to the maximum amounts cumulated in $30 \mathrm{~min}$ are very low (Table 2), indicating a non-extreme character of the precipitations. Relevant intensities were recorded in $10 \mathrm{~min}$. They spanned from a minimum of $32.4 \mathrm{~mm} / \mathrm{h}$ (22 October 2017) to a maximum of $60 \mathrm{~mm} / \mathrm{h}$ (11 September 2017).

The types of alert for possible geo-hydrological processes (floods and landslides) issued by the Campania Region Civil Protection are also reported in Table 2. It is worth explaining that in the Italian alert system, alerts can be issued in two different phases: in phase 1, alerts are based on weather and rainfall forecasts; in phase 2, alerts are based on the real-time measurement of rainfall amounts and on the exceedance of rainfall thresholds predisposed for unburned conditions. Both alerts can be of three types: Yellow (low), orange (moderate), red (high). The extent of the potential affected area, expected damage severity, and consequences to people increases from the yellow to red level. With reference to the analyzed flooding events, only alerts in phase 1 were issued. 

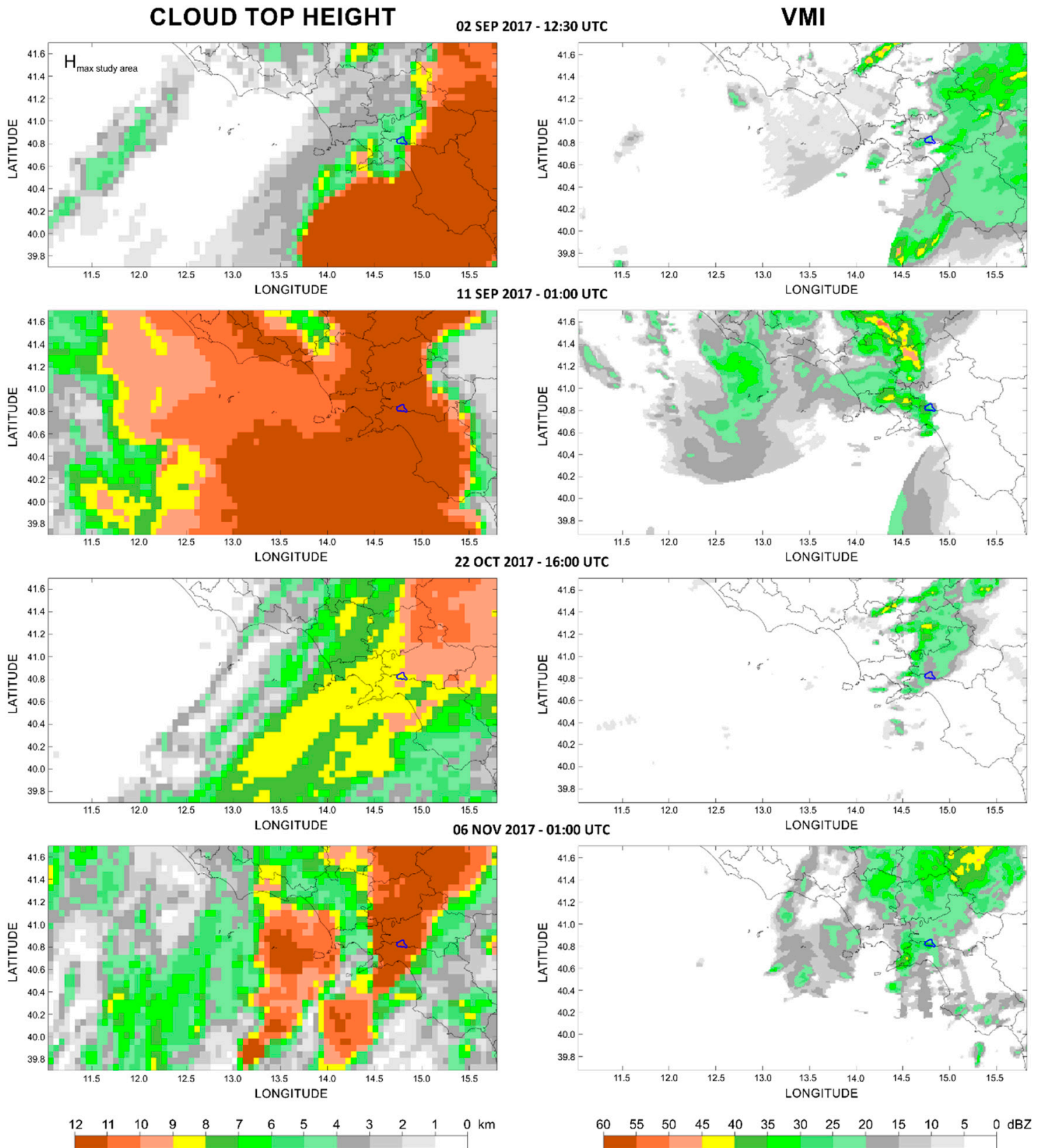

Figure 6. Height of the cloud top (on the left) and radar VMI reflectivity (on the right), referring to approximate flooding initiation times, indicated above the images.

As reported in Table 2, the most severe (orange) concerned the 11 September 2017 and 6 November 2017 events, whereas the less severe (yellow) concerned the other two events. The thresholds predisposed for phase 2 and related to the flash flood risk scenario were too high with respect to the recorded rainfall amounts, in the reference aggregation times of 1,3, and $6 \mathrm{~h}$. In fact, taking as reference the rain gauge used in this study (Bracigliano), a yellow alert is issued if the rain amount exceeds 54 $\mathrm{mm}$ in $3 \mathrm{~h}$ or $64 \mathrm{~mm}$ in $6 \mathrm{~h}$; an orange alert is issued if the rain amount exceeds $71 \mathrm{~mm}$ in $3 \mathrm{~h}$ or $84 \mathrm{~mm}$ in $6 \mathrm{~h}$; a red alert is issued if the rain amount exceeds $58 \mathrm{~mm}$ in $1 \mathrm{~h}, 83 \mathrm{~mm}$ in $3 \mathrm{~h}$, or $98 \mathrm{~mm}$ in $6 \mathrm{~h}$. None of these thresholds were reached during the four flooding events. 
Table 2. Rainfall and radar data related to the analyzed flooding events ( $\operatorname{Max} \mathrm{C}_{30}=$ maximum rainfall cumulated in $30 \mathrm{~min}$; Max $\mathrm{C}_{10}=$ maximum rainfall cumulated in $10 \mathrm{~min}$; Max $\mathrm{I}_{30}=$ maximum 30-min rainfall intensity; Max $\mathrm{I}_{10}=$ maximum 10-min rainfall intensity; RI Max $\mathrm{C}_{30}=$ recurrence interval of the maximum rainfall cumulated in $30 \mathrm{~min}$; $\mathrm{VMI}_{\text {flood response }}=$ radar $\mathrm{VMI}$ reflectivity measured at the approximate time of the flooding initiation over the study area; $\mathrm{VMI}_{\max }$ storm $=$ maximum radar $\mathrm{VMI}$ reflectivity measured during the storm over the study area; $\mathrm{H}_{\text {flood response }}=$ height of the cloud top measured at the approximate time of the flooding initiation over the study area; $\mathrm{H}_{\text {max storm }}=$ maximum height of the cloud top measured during the storm over the study area. Alerts refer to phase 1.

\begin{tabular}{|c|c|c|c|c|}
\hline Event & 2 September 2017 & 11 September 2017 & 22 October 2017 & 6 November 2017 \\
\hline Storm duration (minutes) & 40 & 50 & 110 & 120 \\
\hline Total storm rainfall (mm) & 8.2 & 20 & 27.4 & 45.4 \\
\hline $\operatorname{Max} C_{30}(\mathrm{~mm})$ & 8 & 17.6 & 12.4 & 18 \\
\hline $\operatorname{Max} C_{10}(\mathrm{~mm})$ & 7.4 & 10 & 5.4 & 7.4 \\
\hline $\operatorname{Max}_{30}(\mathrm{~mm} / \mathrm{h})$ & 16 & 35.2 & 24.8 & 36 \\
\hline $\operatorname{Max} \mathrm{I}_{10}(\mathrm{~mm} / \mathrm{h})$ & 44.4 & 60 & 32.4 & 44.4 \\
\hline RI Max $C_{30}$ (years) & 1 & 1.1 & 1 & 1.1 \\
\hline $\mathrm{VMI}_{\text {flood response }}(\mathrm{dBZ})$ & 22 & 26 & 17 & 36 \\
\hline $\mathrm{VMI}_{\max \text { storm }}(\mathrm{dBZ})$ & 24 & 26 & 35 & 36 \\
\hline $\mathrm{H}_{\text {flood response }}(\mathrm{km})$ & 4.5 & 12 & 9 & 12 \\
\hline $\mathrm{H}_{\max \text { storm }}(\mathrm{km})$ & 12 & 12 & 9 & 12 \\
\hline Issued alert & Yellow & Orange & Yellow & Orange \\
\hline
\end{tabular}

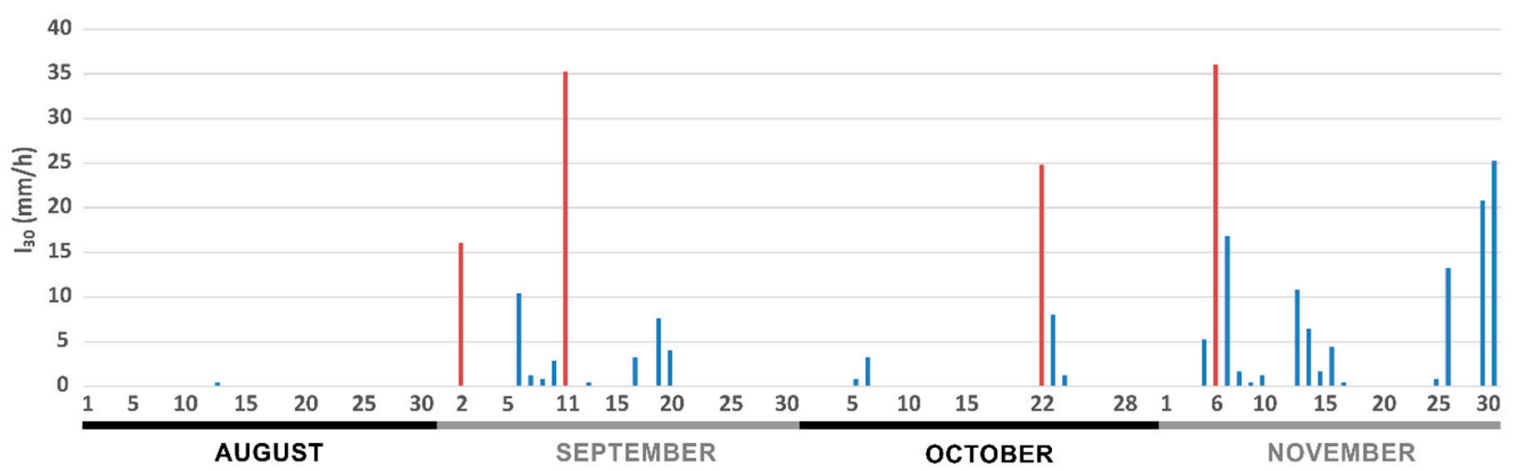

Figure 7. Maximum 30-min rainfall intensities $\left(\mathrm{I}_{30}\right)$ recorded at the Bracigliano rain gauge (Figure 3) in the 1 August-30 November 2017 time period. Red bars are in correspondence to the flooding events.

\subsection{The Impact of Flow Processes in the Urban Area}

Assessment of the information collected by analyzing VGI and crowdsourced observations revealed that the urban sector hit in the four post-fire flooding events was always the same, and corresponded to the zone located downstream with respect to the outlets of watersheds 7,8 and 9 (Figure 8).

As shown in Figures 2 and 8, the outlets of these watersheds are close to the urban area. Here, the natural drainage channels were greatly modified by human interventions. Specifically, channels of watersheds 7 (Figure 8B) and 8 were constrained in small culverts with inadequate channel conveyance capacity to drain sediment-laden flows, whereas the channel of watershed 9 led straight to a road crossing the urban area (Figure $8 \mathrm{~F}$ ). 

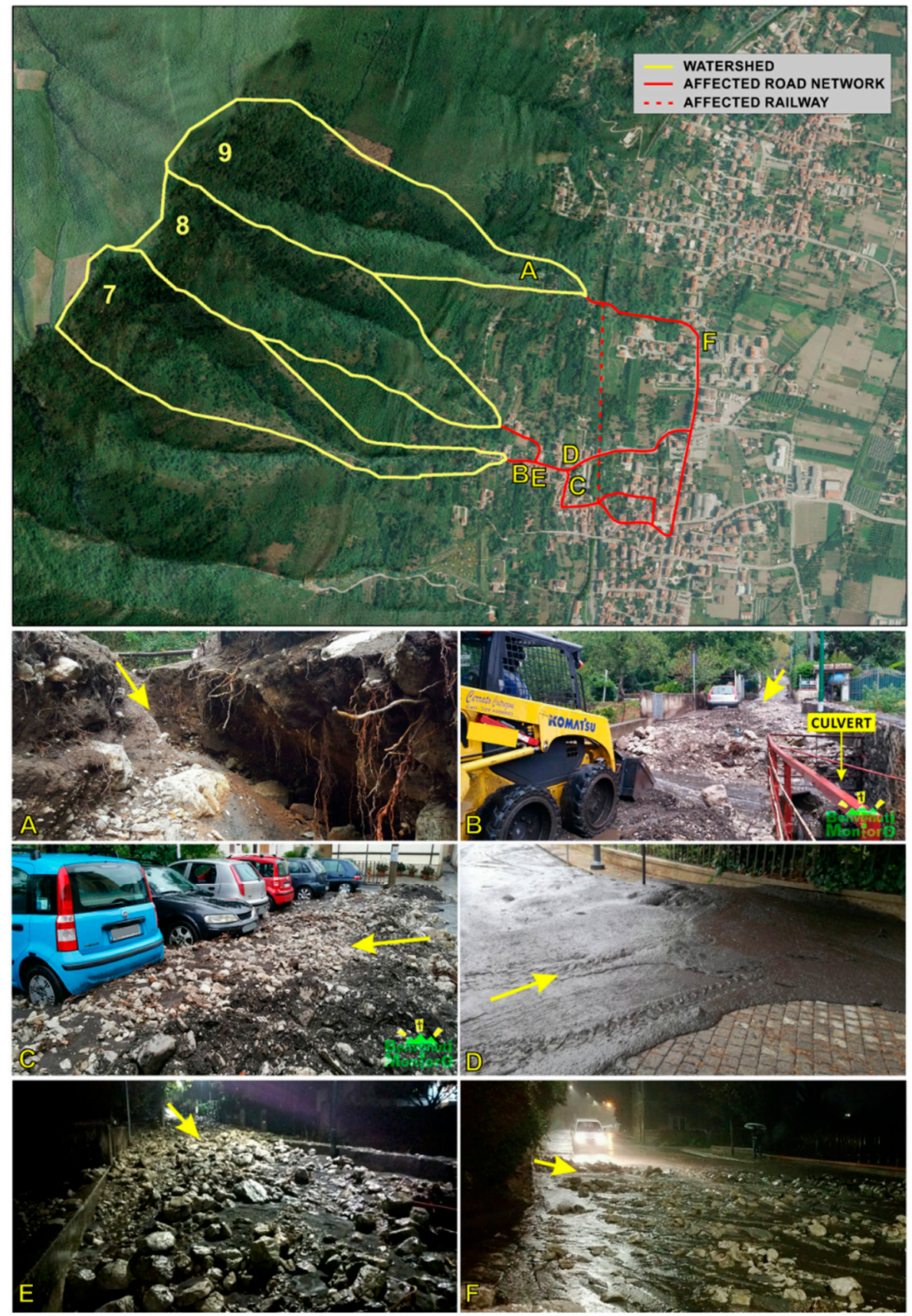

Figure 8. Overview of the urbanized area affected by post-fire flow processes and related watersheds. The photographs below were published on the Facebook webpage, "Benvenuti a Montoro". Photograph (A) highlights a channel bed affected by erosion during the 6 November 2017 event. Photographs from (B-F) show hyperconcentrated and debris flow deposits in different parts of the affected area. Arrows indicate the flow direction.

The analysis of the collected photos and videos highlighted the occurrence of flows transitioning from surface water through to hyperconcentrated flow to debris flow (Table 3). The main evidences resulted from a visual inspection of the portrayed deposits (Figure 9), and in a minor way from some videos captured in real-time during the flow occurrence. 
Table 3. Flow types and damaged anthropic elements characterizing the analyzed events, as indicated by the symbol " $X$ ".

\begin{tabular}{cccccc}
\hline Event & \multicolumn{2}{c}{ Flow Type } & \multicolumn{2}{c}{ Damaged Anthropic Elements } \\
\hline & Water flow & Hyperconcentrated flow & Debris flow & Roads & Buildings \\
2 September 2017 & X & X & & $X$ & $X$ \\
11 September 2017 & X & X & $X$ & $X$ & $X$ \\
22 October 2017 & X & X & $X$ & $X$ & $X$ \\
6 November 2017 & X & $X$ & $X$ & $X$ \\
\hline
\end{tabular}
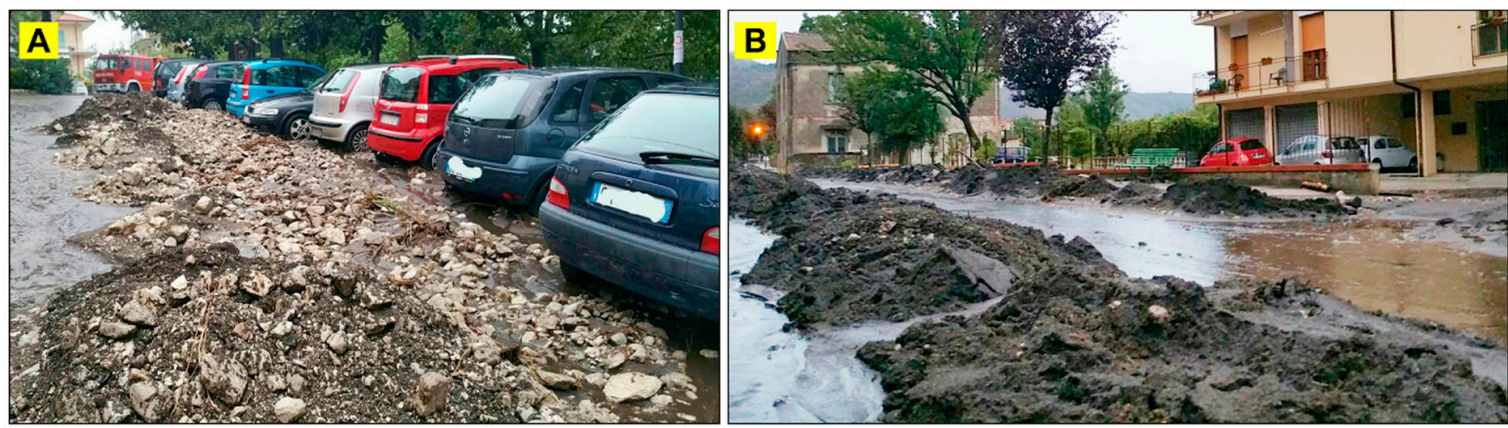

Figure 9. Photographs showing debris flow (A) and hyperconcentrated flow (B) deposits. Both were published on the Facebook webpage "Benvenuti a Montoro".

Generally, debris-rich deposits were located upstream, in the zones close to the watershed outlets, whereas sand-rich deposits (i.e., mud) occurred downstream along the roads (Figure 8).

Quantitative data of deposits volumes were not available. However, by comparing multi-temporal VGI observations, it was noted that both the type and thickness of deposits accumulated in the same areas varied throughout the events, with a kind of direct relationship with the $\mathrm{I}_{30}$ parameter. In other words, the more intense the rain, the greater the quantity and grain size of deposits. In fact, the first event of 2 September 2017 was characterized by rapid hyperconcentrated flows inundating the road network, without consequences for buildings. Deposits consisted in few centimeters of thick layers of brownish mud without debris (Figure 8D). During the second event that occurred on 11 September 2017, flows were richer in fine sediments and debris, coupled with scorched vegetable material (branches and shrubs) (Figure 8B,C). They inundated both roads and the lowest floor of buildings, depositing up to half a meter of material. Effects of the third event (22 October 2017) were similar to those of the previous event, even if deposits were characterized by a minor thickness and debris amounts, overwhelming only the road network. The highest magnitude event of the sequence was the last one, which occurred on 6 November 2017 (Figure 8A,E,F). In this case, flows transported downstream the most relevant amount of fine sediments, debris, and limestone blocks measuring up to $1 \mathrm{~m}^{3}$. Along some roads, deposits exceeded a thickness of $1.5 \mathrm{~m}$, requiring several days to clear both buildings and roads. In this case, the railway was also interrupted.

As maintained by eyewitnesses in the aftermaths, flows pouring along the roads occurred close to the times indicated in Figure 6, producing a deafening sound that was more intense during the second and last events. Injured people or fatalities were not recorded.

\section{Discussion and Conclusions}

The sequence of post-fire flooding events described in this study highlights that wildfires may increase the susceptibility to erosion processes along steep slopes covered by pyroclastic airfall deposits and andosols, with generation of hyperconcentrated and debris flows downstream. This evidence is in accordance with observations made by other authors in similar geological contexts worldwide. Some examples were provided by Meyer and Wells [72] in the Yellowstone National Park (USA) and Neris et al. [20] in the Canary Islands (Spain). In the same mountain chain of the study area, 
post-fire flow processes were documented by De Vita et al. [36] and Esposito et al. [40,41]. It is worth highlighting that both Esposito et al. [40] and field geologists in the Mt. Salto study area did not observe evidences of soil erosion and consequent flow processes in unburned watersheds neighboring to the burned ones. This means that vegetation species covering the analyzed slopes are able to protect soils from the raindrop impact (i.e., rainsplash erosion), sheet wash erosion, and overland flows generation. On the other hand, removal of grass, shrub, and plants, together with changes in hydrologic properties, make andosols highly susceptible to erosion and relevant soil loss. Esposito et al. [40], for example, evaluated a soil loss of about 19.8 to 33.1 tons ha ${ }^{-1}$ in a nearby burned area of 11 ha. As pointed out by Neris et al. [73] for the Canary Islands, erosive processes are non-uniform in space and can be most severe in zones where the soil is bare or covered with a thin ash layer (moderate/high fire severity), and less severe where a residual soil cover is present (low severity). Results of the fire severity assessment reported in Figure 3 show that $64.4 \%$ of the affected area burned with moderate-high severity, and $35.6 \%$ with low severity. These data indicate a significant ecological and geomorphic impact that wildfires have had on the Mt. Salto slopes. Specifically, metrics in Figure 4 display that watersheds 7, 8 and 9 (Figure 8 ) had more than $70 \%$ of their surface burned, with watersheds 7 and 8 being among those most affected by moderate-high severity. These outcomes may ostensibly explain why debris and hyperconcentrated flows occurred right in these watersheds, highlighting a likely correlation between the degree of fire extension/severity and flow response. In addition, it is worth underlining that the impact of flow processes within the corresponding urban area was controlled by a drainage network deeply modified by human interventions, consisting in culverts, concrete channels, and roads. As shown in Figure 8, these structures promoted the spread of rapid flows along roads and buildings on the footslope, posing a serious risk to people.

The four post-fire flood events occurred in response to rainfall that can be considered non-extreme. The maximum amounts recorded in $30 \mathrm{~min}$ were in fact characterized by recurrence intervals of about one year (Table 2). This outcome is in accordance with the findings of Cannon et al. [35] — who verified that storms triggering post-fire debris flows in Colorado and California had recurrence intervals of two years or less-and Moody et al. [31]. With this outcome, it is clear that debris and sediment-laden flows can occur in post-fire settings in response to short-duration and frequent rainfalls that, otherwise, would have no implications in unburned conditions. This means that when a fire occurs, rainfall thresholds developed for warning purposes, and referred to as unburned conditions, are not appropriate to predict the occurrence of post-fire flow processes. This arose during the analyzed events, when no threshold exceedance was recorded and no alert was issued in phase 2 (forthcoming event) to warn people. In similar situations, thresholds should thus be re-defined together with procedures for emergency responses. To calibrate and validate empirical thresholds, however, a consistent number of post-fire events that have already occurred in the same area, together with related triggering rainfalls, are required [74]. Data presented in this study should also be used for this purpose, as well as for building specific susceptibility models aimed at predicting the possible occurrence of post-fire processes.

Even in case of suitable thresholds and efficient real-time monitoring of rainfall, the rapid response of small watersheds, like those characterizing the Mt. Salto area (e.g., Table 1), to localized rainfall pulses might not allow to warn the population with a sufficient lead time. Therefore, as also suggested by Staley et al. [75], the improvement of rainfall intensity forecasting and monitoring of rainfall conditions upwind of the area of concern are of utmost importance for early warning purposes. Weather radars can support this type of activity providing, with high temporal resolution (i.e., minutes), estimation of precipitation amounts and intensities in areas remote from rain gauges. Radar data considered in this study could have efficiently supported emergency responses during the analyzed events. As shown in Appendix A, in all cases, the radar data allowed to identify frontal systems approaching the study area. We estimated in three hours the average time between system detection and impact in the study area. The first event was associated to an isolated convective cell, which was formed four hours after the impact of the frontal system. In this case, VMI reflectivity data highlighted a large-scale storm, but were not able to identify the cell. 
Besides radar reflectivity, the height of the cloud top estimated from satellite data could have been also useful to detect storms and obtain information on their potential severity. For instance, cloud top heights of about $12 \mathrm{~km}$ (11 September 2017 and 6 November 2017 events in Figure 6) indicate cumulonimbus clouds that are able to generate intense rainfall and hail (e.g., [76]). At the same time, autoregenerating V-shaped convective cells, like the one formed during the 6 November 2017 major event (Figure 6), are systems able to release persistent and intense rainfalls in a given location [77,78]. Taking into account all these considerations, as well as drawbacks affecting remote sensing technologies, we believe that if specific numerical models had been available, both radar and satellite data would have allowed to track and forecast the spatial and temporal evolution of the convective systems that impacted the study area $[79,80]$. If coupled with suitable rainfall thresholds, they could have been also used in operational early warning systems aimed at risk reduction.

A final remark concerns the relatively limited impact that the debris and sediment-laden flow processes had on the urbanized area in terms of damage (i.e., no people involved and no building collapse). The most severe events in the sequence, in terms of mobilized material and damage to the urban settlements, occurred overnight (11 September 2017 and 6 November 2017), when people were inside their homes and cars were thus empty. This circumstance helped prevent casualties and fatalities. In our opinion, however, another important condition that limited consequences on people and settlements was the gradual mobilization of unstable material throughout four different flooding events, characterized by a moderate magnitude in terms of mobilized material. We believe that if the area had been hit by a unique convective storm characterized by extreme precipitation, almost all unstable material along steep slopes would have been mobilized at once. In this case, overland flows would have been able to progressively increase their sediment concentration and their capacity to erode hillslopes and channels downstream, with the possibility of evolving into more destructive debris flows. The documented sequence highlights, however, that the hazard related to debris and sediment-laden flows may persist in burned watersheds for an undefined time, until all the unstable material is mobilized.

Author Contributions: Conceptualization, G.E.; resources, R.M., A.P., M.L., S.A.; G.G.; data curation, G.E., R.M., A.P., G.N. and F.R.; writing—original draft preparation, G.E., G.G., S.A. and A.P.; writing—review and editing, G.E.

Funding: This research received no external funding.

Acknowledgments: We are grateful to the following institutions: Dipartimento Nazionale della Protezione Civile for authorizing the use of radar data; Centro Funzionale Multirischi della Protezione Civile Regione Campania for providing rainfall data; and Comune di Montoro for providing technical information related to the effects of flooding processes.

Conflicts of Interest: The authors declare no conflict of interest.

\section{Appendix A}

Temporal and spatial evolution of the cloud top height and radar reflectivity over the study area, throughout the analyzed flooding events. A time step of one hour was chosen to represent meteorological conditions before, during, and after the flooding. 
CLOUD TOP HEIGHT
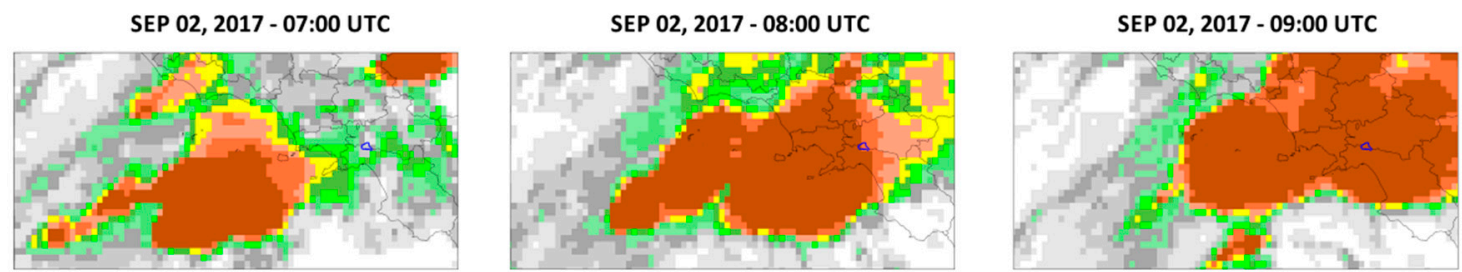

SEP 02, 2017 - 10:00 UTC

SEP 02, 2017 - 11:00 UTC

SEP 02, 2017 - 12:00 UTC

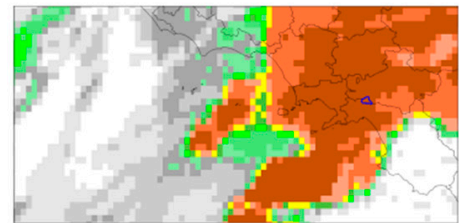

SEP 02, 2017 - 13:00 UTC

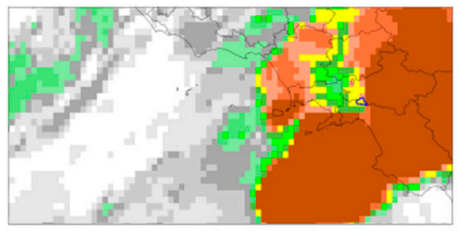

SEP 02, 2017 - 14:00 UTC

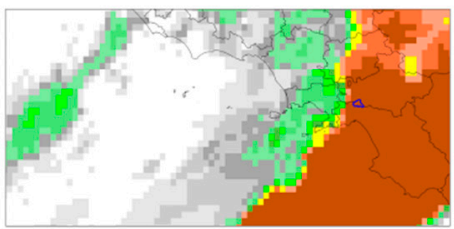

SEP 02, 2017 - 15:00 UTC
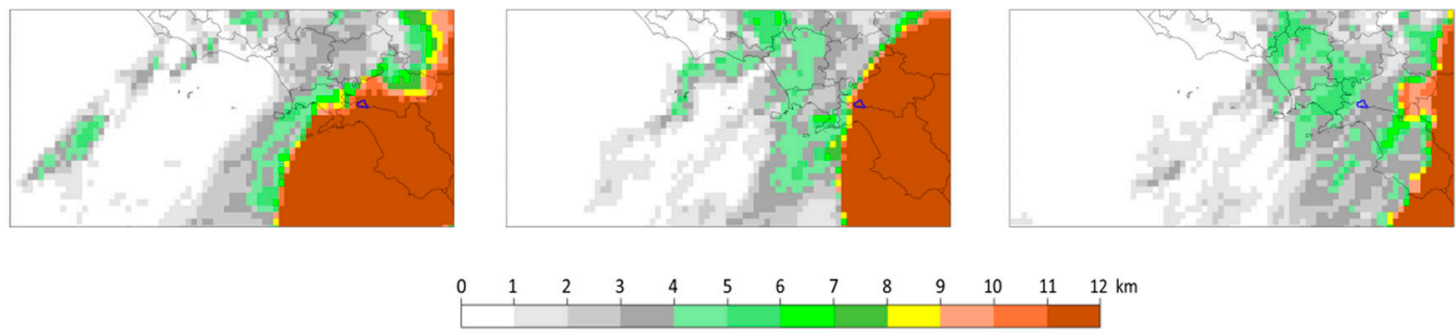

\section{RADAR REFLECTIVITY (VMI)}

SEP 02, 2017 - 07:00 UTC

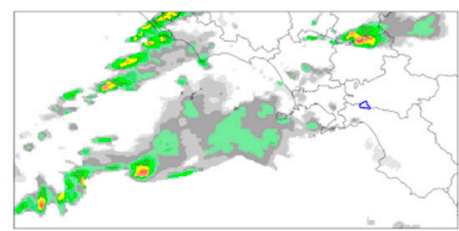

SEP 02, 2017 - 10:00 UTC

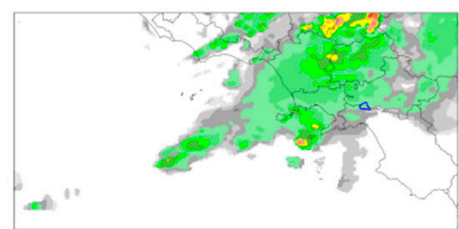

SEP 02, 2017 - 13:00 UTC

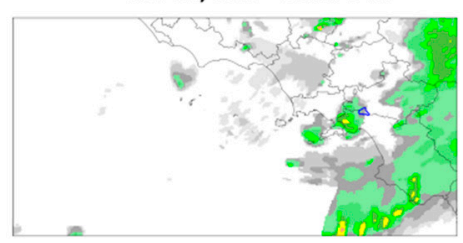

SEP 02, 2017 - 08:00 UTC

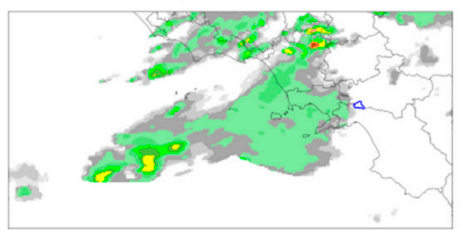

SEP 02, 2017 - 11:00 UTC

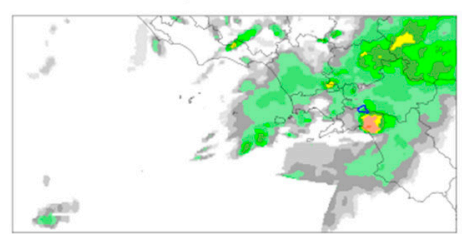

SEP 02, 2017 - 14:00 UTC

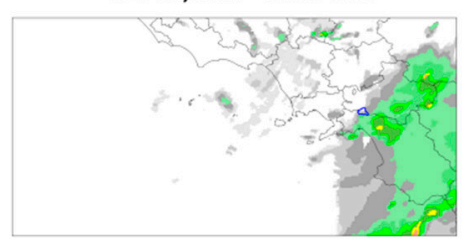

SEP 02, 2017 - 09:00 UTC

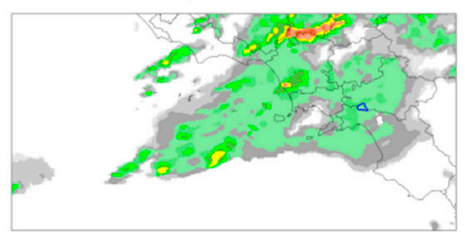

SEP 02, 2017 - 12:00 UTC

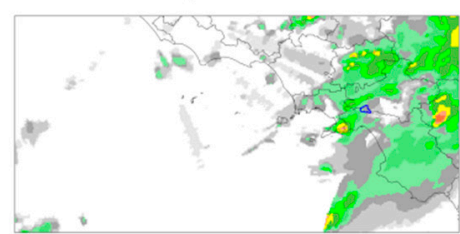

SEP 02, 2017 - 15:00 UTC

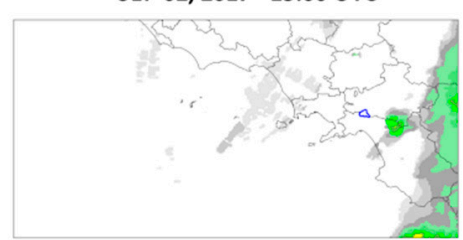

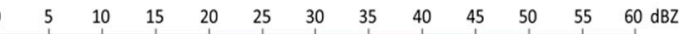

Figure A1. Cloud top height and radar reflectivity for the 2 September 2017 event. The study area is highlighted in blue. 


\section{CLOUD TOP HEIGHT}

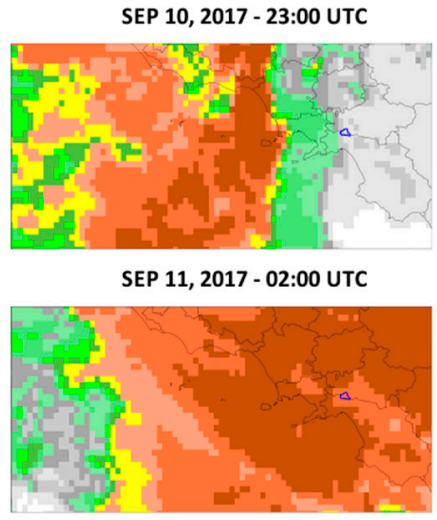

SEP 02, 2017 - 05:00 UTC

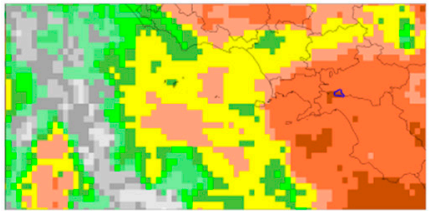

SEP 11, 2017 - 00:00 UTC

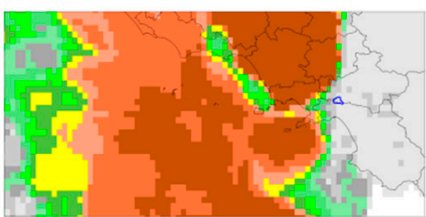

SEP 11, 2017 - 03:00 UTC

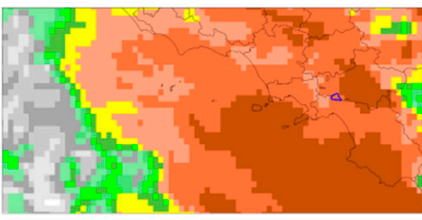

SEP 02, 2017 - 06:00 UTC

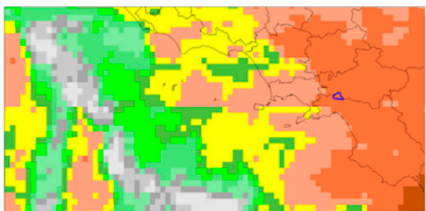

SEP 11, 2017 - 01:00 UTC

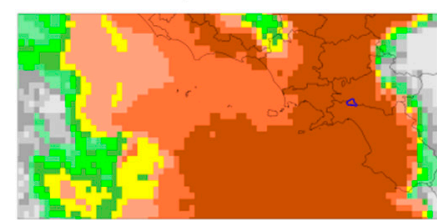

SEP 11, 2017 - 04:00 UTC

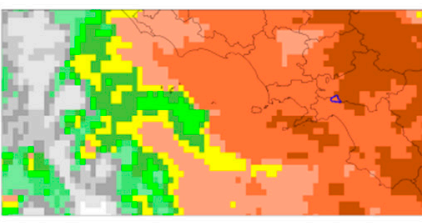

SEP 02, 2017 - 07:00 UTC

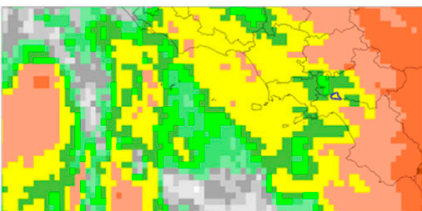

\begin{tabular}{lllllllllllll}
0 & 1 & 2 & 3 & 4 & 5 & 6 & 7 & 8 & 9 & 10 & 11 & $12 \mathrm{~km}$ \\
\hline
\end{tabular}

\section{RADAR REFLECTIVITY (VMI)}
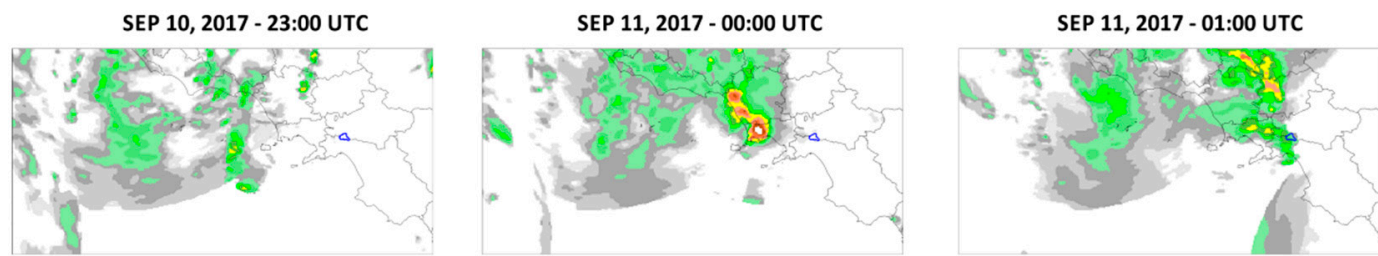

SEP 11, 2017 - 02:00 UTC
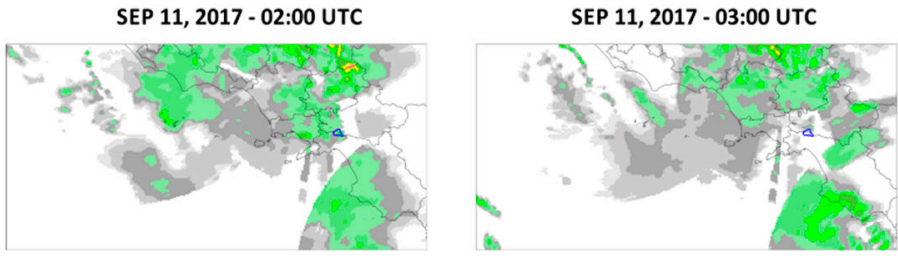

SEP 11, 2017 - 06:00 UTC

SEP 11, 2017 - 04:00 UTC

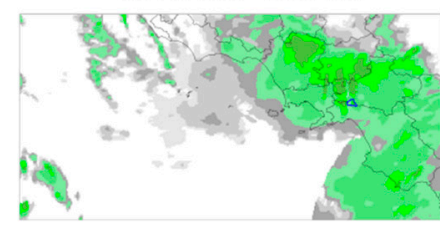

SEP 11, 2017 - 05:00 UTC
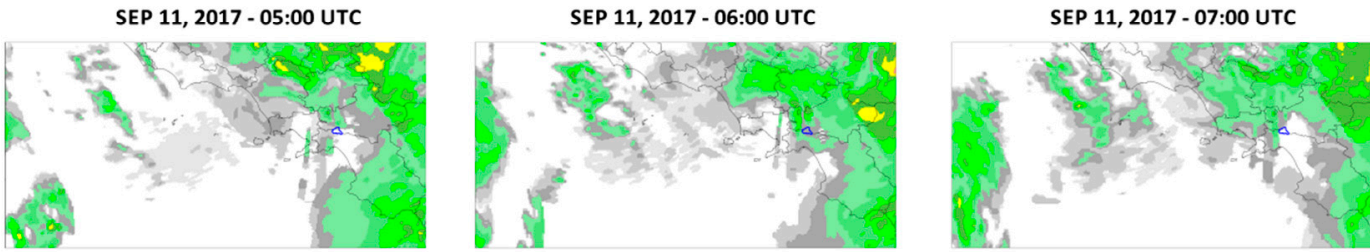

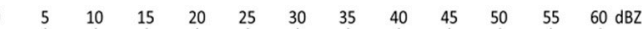

Figure A2. Cloud top height and radar reflectivity for the 11 September 2017 event. The study area is highlighted in blue. 


\section{CLOUD TOP HEIGHT}
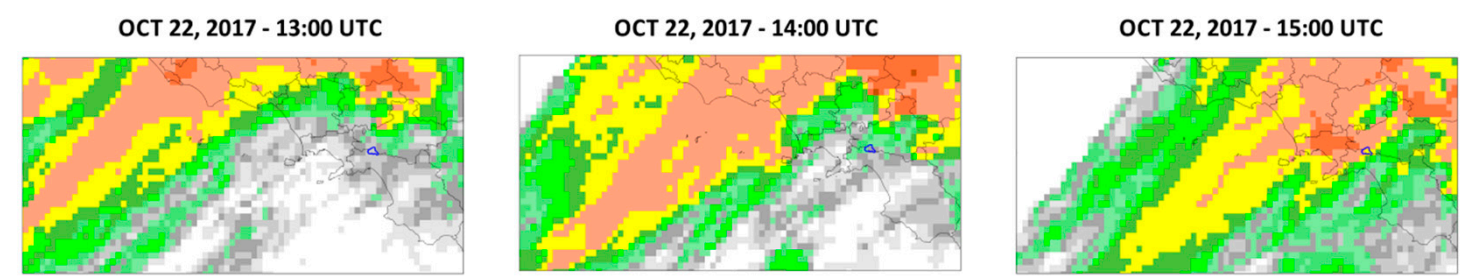

OCT 22, 2017 - 16:00 UTC

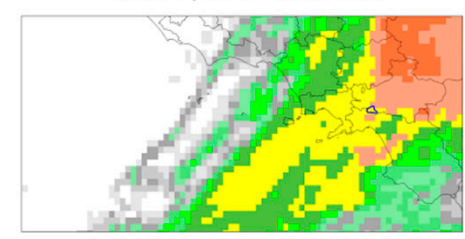

OCT 22, 2017 - 17:00 UTC

OCT 22, 2017 - 18:00 UTC
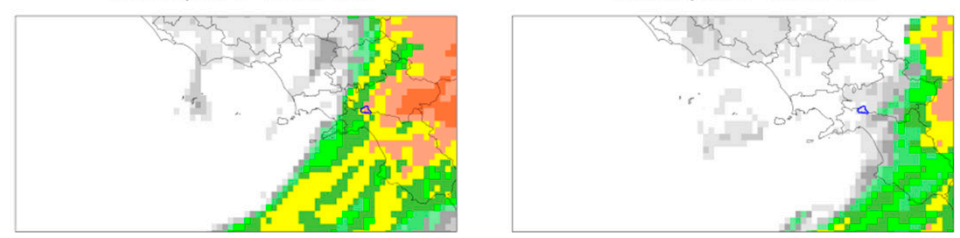

\begin{tabular}{lllllllllllll}
0 & 1 & 2 & 3 & 4 & 5 & 6 & 7 & 8 & 9 & 10 & 11 & $12 \mathrm{~km}$ \\
\hline
\end{tabular}

\section{RADAR REFLECTIVITY (VMI)}

OCT 22, 2017 - 13:00 UTC

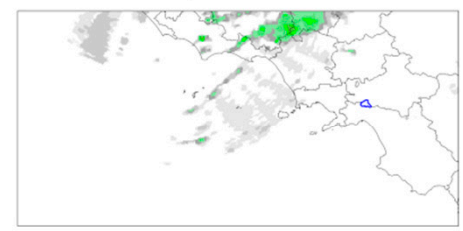

OCT 22, 2017 - 16:00 UTC

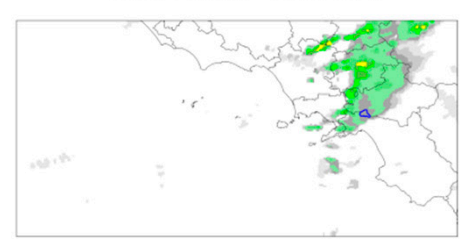

OCT 22, 2017 - 14:00 UTC

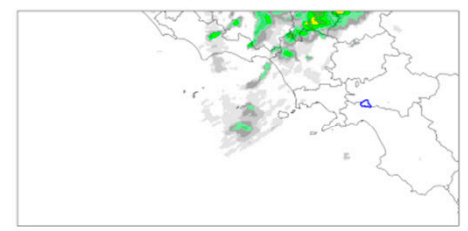

OCT 22, 2017 - 17:00 UTC

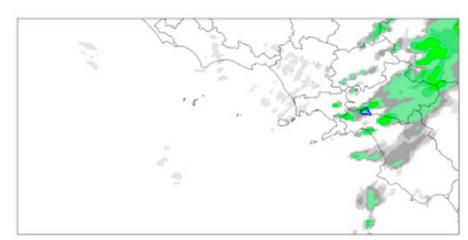

OCT 22, 2017 - 15:00 UTC

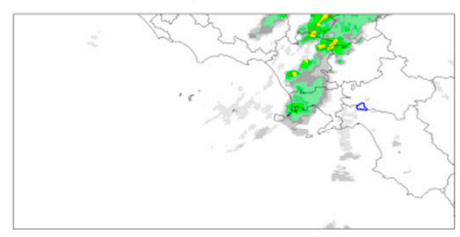

OCT 22, 2017 - 18:00 UTC

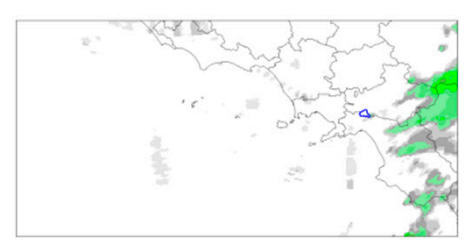

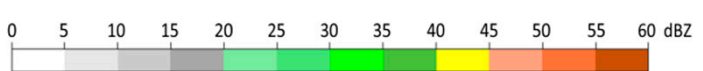

Figure A3. Cloud top height and radar reflectivity for the 22 October 2017 event. The study area is highlighted in blue. 


\section{CLOUD TOP HEIGHT}

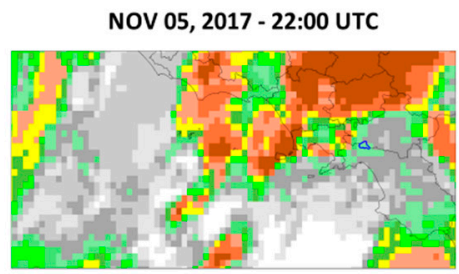

NOV 06, 2017 - 01:00 UTC
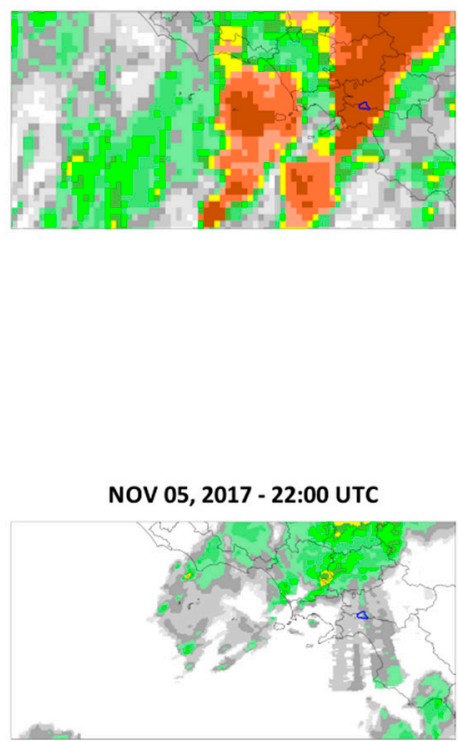

NOV 06, 2017 - 01:00 UTC

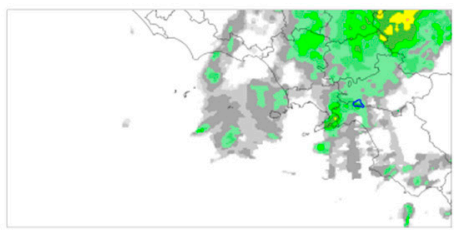

NOV 05, 2017 - 23:00 UTC

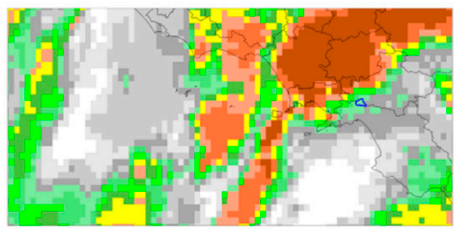

NOV 06, 2017 - 02:00 UTC

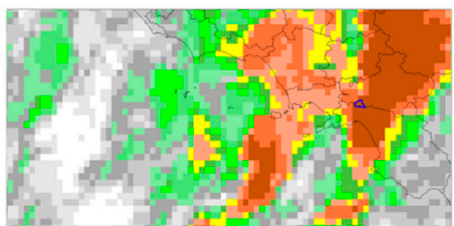

$\begin{array}{llllllllllll}1 & 2 & 3 & 4 & 5 & 6 & 7 & 8 & 9 & 10 & 11 & 12 \mathrm{~km}\end{array}$

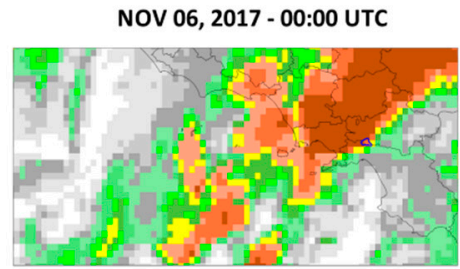

NOV 06, 2017 - 03:00 UTC

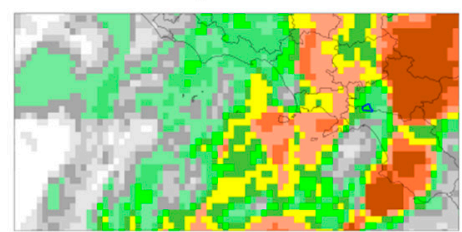

\section{RADAR REFLECTIVITY (VMI)}

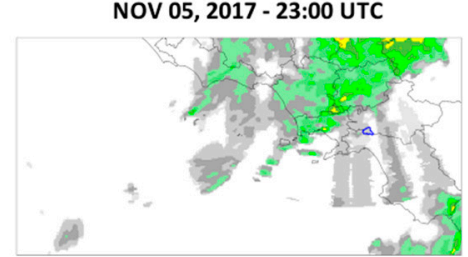

NOV 06, 2017 - 02:00 UTC

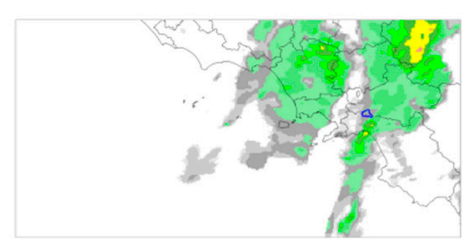

NOV 06, 2017 - 00:00 UTC

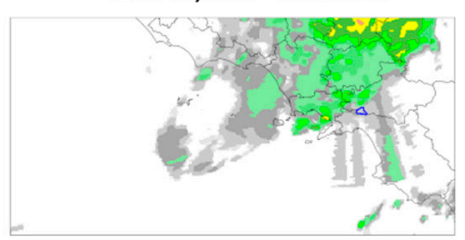

NOV 06, 2017 - 03:00 UTC

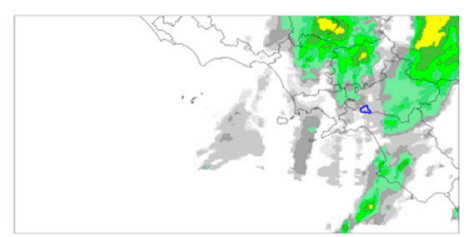

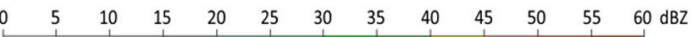

Figure A4. Cloud top height and radar reflectivity for the 6 November 2017 event. The study area is highlighted in blue.

\section{References}

1. Arca, B.; Salis, M.; Pellizzaro, G.; Bacciu, V.; Spano, D.; Duce, P.; Ager, A.A.; Finney, M.A. Climate change impact on fire probability and severity in Mediterranean areas. In Proceedings of the VI International Conference on Forest Fire Research, Coimbra, Portugal, 15-18 November 2010; pp. 5-18.

2. Lozano, O.M.; Salis, M.; Ager, A.A.; Arca, B.; Alcasena, F.J.; Monteiro, A.T.; Finney, M.A.; Del Giudice, L.; Scoccimarro, E.; Spano, D. Assessing Climate Change Impacts on Wildfire Exposure in Mediterranean Areas. Risk Anal. 2017, 37, 1898-1916. [CrossRef] [PubMed]

3. Meyer, G.A.; Pierce, J.L. Climatic controls on fire-induced sediment pulses in Yellowstone National Park and central Idaho: A long-term perspective. For. Ecol. Manag. 2003, 178, 89-104. [CrossRef]

4. Keeley, J.E. Fire intensity, fire severity and burn severity: A brief review and suggested usage. Int. J. Wildland Fire 2009, 18, 116-126. [CrossRef]

5. Key, C.H.; Benson, N.C. Landscape Assessment (LA) Sampling and Analysis Methods; Gen. Tech. Rep. RMRS-GTR-164-CD; USDA Forest Service: Washington, DC, USA, 2006. 
6. Parsons, A.; Robichaud, P.R.; Lewis, S.A.; Napper, C.; Clark, J.T. Field Guide for Mapping Post-Fire Soil Burn Severity; Gen. Tech. Rep. RMRS GTR; USDA Forest Service: Washington, DC, USA, 2010; Volume 243, pp. 1-49.

7. Lentile, L.B.; Holden, Z.A.; Smith, A.M.S.; Falkowski, M.J.; Hudak, A.T.; Morgan, P.; Lewis, S.A.; Gessler, P.E.; Benson, N.C. Remote sensing techniques to assess active fire characteristics and post-fire effects. Int. J. Wildland Fire 2006, 15, 319-345. [CrossRef]

8. Mallinis, G.; Mitsopoulos, I.; Chrysafi, I. Evaluating and comparing sentinel 2A and landsat-8 operational land imager (OLI) spectral indices for estimating fire severity in a mediterranean pine ecosystem of Greece. Gisci. Remote Sens. 2018, 55,1-18. [CrossRef]

9. Carvajal-Ramírez, F.; da Silva, J.R.M.; Agüera-Vega, F.; Martínez-Carricondo, P.; Serrano, J.; Moral, F.J. Evaluation of fire severity indices based on pre- and post-fire multispectral imagery sensed from UAV. Remote Sens. 2019, 11, 993. [CrossRef]

10. Van Wagtendonk, J.W.; Root, R.R.; Key, C.H. Comparison of AVIRIS and Landsat ETM + detection capabilities for burn severity. Remote Sens. Environ. 2004, 92, 397-408. [CrossRef]

11. García-Llamas, P.; Suárez-Seoane, S.; Fernández-Guisuraga, J.M.; Fernández-García, V.; Fernández-Manso, A.; Quintano, C.; Taboada, A.; Marcos, E.; Calvo, L. Evaluation and comparison of Landsat 8, Sentinel-2 and Deimos-1 remote sensing indices for assessing burn severity in Mediterranean fire-prone ecosystems. Int. J. Appl. Earth Obs. Geoinf. 2019, 80, 137-144. [CrossRef]

12. Escuin, S.; Navarro, R.; Fernández, P. Fire severity assessment by using NBR (Normalized Burn Ratio) and NDVI (Normalized Difference Vegetation Index) derived from LANDSAT TM/ETM images. Int. J. Remote Sens. 2008, 29, 1053-1073. [CrossRef]

13. Veraverbeke, S.; Lhermitte, S.; Verstraeten, W.W.; Goossens, R. Evaluation of pre/post-fire differenced spectral indices for assessing burn severity in a Mediterranean environment with Landsat Thematic Mapper. Int. J. Remote Sens. 2011, 32, 3521-3537. [CrossRef]

14. Veraverbeke, S.; Verstraeten, W.W.; Lhermitte, S.; Goossens, R. Evaluating Landsat Thematic Mapper spectral indices for estimating burn severity of the 2007 Peloponnese wildfires in Greece. Int. J. Wildland Fire 2010, 19, 558-569. [CrossRef]

15. French, N.H.F.; Kasischke, E.S.; Hall, R.J.; Murphy, K.A.; Verbyla, D.L.; Hoy, E.E.; Allen, J.L. Using Landsat data to assess fire and burn severity in the North American boreal forest region: An overview and summary of results. Int. J. Wildland Fire 2008, 17, 443-462. [CrossRef]

16. Sobrino, J.A.; Llorens, R.; Fernández, C.; Fernández-Alonso, J.M.; Vega, J.A. Relationship between forest fires severity measured in situ and through remotely sensed spectral indices. Forests 2019, 10, 457. [CrossRef]

17. Allen, J.L.; Sorbel, B. Assessing the differenced Normalized Burn Ratio's ability to map burn severity in the boreal forest and tundra ecosystems of Alaska's national parks. Int. J. Wildland Fire 2008, 17, 463-475. [CrossRef]

18. Soverel, N.O.; Perrakis, D.D.B.; Coops, N.C. Estimating burn severity from Landsat dNBR and RdNBR indices across western Canada. Remote Sens. Environ. 2010, 114, 1896-1909. [CrossRef]

19. Rulli, M.C.; Bozzi, S.; Spada, M.; Bocchiola, D.; Rosso, R. Rainfall simulations on a fire disturbed mediterranean area. J. Hydrol. 2006, 327, 323-338. [CrossRef]

20. Neris, J.; Santamarta, J.C.; Doerr, S.H.; Prieto, F.; Agulló-Pérez, J.; García-Villegas, P. Post-fire soil hydrology, water erosion and restoration strategies in andosols: A review of evidence from the Canary Islands (Spain). iForest 2016, 9, 583-592. [CrossRef]

21. Moody, J.A.; Martin, D.A.; Haire, S.L.; Kinner, D.A. Linking runoff response to burn severity after a wildfire. Hydrol. Process. 2008, 22, 2063-2074. [CrossRef]

22. Gartner, J.E.; Cannon, S.H.; Santi, P.M. Empirical models for predicting volumes of sediment deposited by debris flows and sediment-laden floods in the transverse ranges of southern California. Eng. Geol. 2014, 176, 45-56. [CrossRef]

23. Doerr, S.H.; Shakesby, R.A.; Walsh, R.P.D. Soil water repellency: Its causes, characteristics and hydro-geomorphological significance. Earth Sci. Rev. 2000, 51, 33-65. [CrossRef]

24. DeBano, L.F. The role of fire and soil heating on water repellency in wildland environments: A review. J. Hydrol. 2000, 231-232, 195-206. [CrossRef]

25. Jordán, A.; Zavala, L.M.; Mataix-Solera, J.; Nava, A.L.; Alanís, N. Effect of fire severity on water repellency and aggregate stability on Mexican volcanic soils. Catena 2011, 84, 136-147. [CrossRef] 
26. Moody, J.A.; Ebel, B.A. Hyper-dry conditions provide new insights into the cause of extreme floods after wildfire. Catena 2012, 93, 58-63. [CrossRef]

27. Weninger, T.; Filipović, V.; Mešić, M.; Clothier, B.; Filipović, L. Estimating the extent of fire induced soil water repellency in Mediterranean environment. Geoderma 2019, 338, 187-196. [CrossRef]

28. Parise, M.; Cannon, S.H. Wildfire impacts on the processes that generate debris flows in burned watersheds. Nat. Hazards 2012, 61, 217-227. [CrossRef]

29. Kean, J.W.; Staley, D.M.; Lancaster, J.T.; Rengers, F.K.; Swanson, B.J.; Coe, J.A.; Hernandez, J.L.; Sigman, A.J.; Allstadt, K.E.; Lindsay, D.N. Inundation, flow dynamics, and damage in the 9 January 2018 Montecito debris-flow event, California, USA: Opportunities and challenges for post-wildfire risk assessment. Geosphere 2019, 15, 1140-1163. [CrossRef]

30. Cui, Y.; Cheng, D.; Chan, D. Investigation of post-fire debris flows in Montecito. ISPRS Int. J. Geo Inf. 2019, 8, 5. [CrossRef]

31. Moody, J.A.; Shakesby, R.A.; Robichaud, P.R.; Cannon, S.H.; Martin, D.A. Current research issues related to post-wildfire runoff and erosion processes. Earth Sci. Rev. 2013, 122, 10-37. [CrossRef]

32. Cannon, S.H.; Boldt, E.M.; Laber, J.L.; Kean, J.W.; Staley, D.M. Rainfall intensity-duration thresholds for postfire debris-flow emergency-response planning. Nat. Hazards 2011, 59, 209-236. [CrossRef]

33. Restrepo, P.; Jorgensen, D.P.; Cannon, S.H.; Costa, J.; Laber, J.; Major, J.; Martner, B.; Purpura, J.; Werner, K. Joint NOAA/NWS/USGS prototype debris flow warning system for recently burned areas in Southern California. Bull. Am. Meteorol. Soc. 2008, 89, 1845-1851. [CrossRef]

34. Staley, D.M.; Negri, J.A.; Kean, J.W.; Laber, J.L.; Tillery, A.C.; Youberg, A.M. Prediction of spatially explicit rainfall intensity-duration thresholds for post-fire debris-flow generation in the western United States. Geomorphology 2017, 278, 149-162. [CrossRef]

35. Cannon, S.H.; Gartner, J.E.; Wilson, R.C.; Bowers, J.C.; Laber, J.L. Storm rainfall conditions for floods and debris flows from recently burned areas in southwestern Colorado and southern California. Geomorphology 2008, 96, 250-269. [CrossRef]

36. De Vita, P.; Guadagno, C.; Lanzara, R.; Lombardi, G.; Tarantino, E.; Vallario, A. L'evento alluvionale del 20 agosto 1993 nei territori comunali di Solofra e Serino (Avellino-Campania). In Proceedings of the VIII Congresso Nazionale Geologi, Roma, Italy, 21-23 January 1994; pp. 165-171.

37. Candela, A.; Aronica, G.; Santoro, M. Effects of Forest Fires on Flood Frequency Curves in a Mediterranean Catchment. Hydrol. Sci. J. 2005, 50, 193-206. (In French) [CrossRef]

38. Calcaterra, D.; Parise, M.; Strumia, S.; Mazzella, E. Relations between Fire, Vegetation and Landslides in the Heavily Populated Metropolitan Area of Naples, Italy. In Proceedings of the 1st North American Landslides Conference, Vail, CO, USA, 3-8 June 2007; AEG Special Publication, Omnipress: Madison, WI, USA, 2007; Volume 23, pp. 1448-1461.

39. Rossi, M.; Torri, D.; Santi, E.; Bacaro, G.; Mondini, A.C.; Reichenbach, P.; Fiorucci, F.; Marchesini, I. Evaluating the impact of fires on slope instability processes: A case study in Central Italy (Invited). In Proceedings of the AGU 2013 Fall Meeting, San Francisco, CA, USA, 9-13 December 2013.

40. Esposito, G.; Matano, F.; Molisso, F.; Ruoppolo, G.; Di Benedetto, A.; Sacchi, M. Post-fire erosion response in a watershed mantled by volcaniclastic deposits, Sarno Mountains, Southern Italy. Catena 2017, 152, 227-241. [CrossRef]

41. Esposito, G.; Esposito, E.; Matano, F.; Molisso, F.; Sacchi, M.; Porfido, S. Effects of a wildfire on rocks and soils in the Sarno Mountains, Campania, Southern Apennines. Rend. Online Soc. Geol. Ital. 2013, 24, 119-121.

42. Carabella, C.; Miccadei, E.; Paglia, G.; Sciarra, N. Post-wildfire landslide hazard assessment: The case of the 2017 montagna del morrone fire (central apennines, Italy). Geosciences 2019, 9, 175. [CrossRef]

43. Tiranti, D.; Moscariello, A.; Giudici, I.; Rabuffetti, D.; Cremonini, R.; Campana, V.; Bosco, F.; Giardino, M. Post-fire rainfall events influence on debris-flows trigger mechanisms, evolution and sedimentary processes: The Rio Casella case study in the North-western Italian Alps. Geophys. Res. Abstr. 2006, 8, 03479.

44. Agenzia Regionale per la Protezione Ambientale Piemonte (ARPA). Rapporto evento del 7 June 2018-Colata detritica nel Comune di Bussoleno. Available online: https://www.arpa.piemonte.it/arpa-comunica/filenotizie/2018/rapporto-evento-bussoleno2.pdf (accessed on 14 October 2019).

45. Pierson, T.C. Hyperconcentrated flow-Transitional process between water flow and debris flow. In Debris-flow Hazards and Related Phenomena; Springer Praxis Books; Jakob, M., Hungr, O., Eds.; Springer: Berlin/Heidelberg, Germany, 2005. 
46. Rolandi, G.; Petrosino, P.; Mc Geehin, J. The interplinian activity at Somma-Vesuvius in the last 3500 years. J. Volcanol. Geotherm. Res. 1998, 82, 19-52. [CrossRef]

47. Cole, P.D.; Scarpati, C. The 1944 eruption of Vesuvius, Italy: Combining contemporary accounts and field studies for a new volcanological reconstruction. Geol. Mag. 2010, 147, 391-415. [CrossRef]

48. De Vita, P.; Fusco, F.; Tufano, R.; Cusano, D. Seasonal and event-based hydrological and slope stability modeling of pyroclastic fall deposits covering slopes in Campania (Southern Italy). Water 2018, 10, 1140. [CrossRef]

49. WRB. World Reference base for Soil Resources, Reports, 103; FAO Press: Rome, Italy, 2006.

50. Maeda, T.; Takenaka, H.; Warkentin, B.P. Physical Properties of Allophane Soils. Adv. Agron. 1977, 29, 229-264.

51. Warkentin, B.P. Physical Properties of Forest-Nursery Soils: Relation to Seedling Growth. In Forestry Nursery Manual: Production of Bareroot Seedlings; Duryea, M.L., Landis, T.D., Perry, C.R., Eds.; Springer: Dordrecht, The Netherlands, 1984; pp. 53-61. ISBN 978-94-009-6110-4.

52. Rodríguez Rodríguez, A.; Guerra, J.A.; Gorrín, S.P.; Arbelo, C.D.; Mora, J.L. Aggregates stability and water erosion in Andosols of the Canary Islands. Land Degrad. Dev. 2002, 13, 515-523. [CrossRef]

53. Mobilia, M.; Califano, F.; Longobardi, A. Analysis of Rainfall Events Driving MDHEs Occurred in the Solofrana River Basin, Southern Italy. Procedia Eng. 2015, 119, 1139-1146. [CrossRef]

54. Napolitano, E.; Fusco, F.; Baum, R.L.; Godt, J.W.; De Vita, P. Effect of antecedent-hydrological conditions on rainfall triggering of debris flows in ash-fall pyroclastic mantled slopes of Campania (southern Italy). Landslides 2016, 13, 967-983. [CrossRef]

55. Budetta, P.; de Riso, R. The mobility of some debris flows in pyroclastic deposits of the northwestern Campanian region (southern Italy). Bull. Eng. Geol. Environ. 2004, 63, 293-302. [CrossRef]

56. Longobardi, A.; Diodato, N.; Mobilia, M. Historical storminess and hydro-geological hazard temporal evolution in the Solofrana River Basin-Southern Italy. Water 2016, 8, 398. [CrossRef]

57. European Space Agency. User Guides SENTINEL-2 MSI Introduction. 2015. Available online: https: //sentinel.esa.int/web/sentinel/user-guides/sentinel-2-msi (accessed on 9 October 2019).

58. European Space Agency. User Guides SENTINEL-2 MSI Product Types Level-1C. 2015. Available online: https://sentinel.esa.int/web/sentinel/user-guides/sentinel-2-msi/product-types/level-1c (accessed on 9 October 2019).

59. Huang, H.; Roy, D.P.; Boschetti, L.; Zhang, H.K.; Yan, L.; Kumar, S.S.; Gomez-Dans, J.; Li, J. Separability analysis of Sentinel-2A Multi-Spectral Instrument (MSI) data for burned area discrimination. Remote Sens. 2016, 8, 873. [CrossRef]

60. Vulpiani, G.; Tabary, P.; Parent du Chatelet, J.; Marzano, F.S. Comparison of Advanced Radar Polarimetric Techniques for Operational Attenuation Correction at C Band. J. Atmos. Ocean. Technol. 2008, 25, 1118-1135. [CrossRef]

61. Esposito, G.; Matano, F.; Scepi, G. Analysis of Increasing Flash Flood Frequency in the Densely Urbanized Coastline of the Campi Flegrei Volcanic Area, Italy. Front. Earth Sci. 2018, 6, 63. [CrossRef]

62. Brouwer, T.; Eilander, D.; van Loenen, A.; Booij, M.J.; Wijnberg, K.M.; Verkade, J.S.; Wagemaker, J. Probabilistic flood extent estimates from social media flood observations. Nat. Hazards Earth Syst. Sci. 2017, 17, 735-747. [CrossRef]

63. Restrepo-Estrada, C.; de Andrade, S.C.; Abe, N.; Fava, M.C.; Mendiondo, E.M.; de Albuquerque, J.P. Geo-social media as a proxy for hydrometeorological data for streamflow estimation and to improve flood monitoring. Comput. Geosci. 2018, 111, 148-158. [CrossRef]

64. Mazzoleni, M.; Verlaan, M.; Alfonso, L.; Monego, M.; Norbiato, D.; Ferri, M.; Solomatine, D.P. Can assimilation of crowdsourced data in hydrological modelling improve flood prediction? Hydrol. Earth Syst. Sci. 2017, 21, 839-861. [CrossRef]

65. Diakakis, M.; Deligiannakis, G.; Katsetsiadou, K.; Lekkas, E.; Melaki, M.; Antoniadis, Z. Mapping and classification of direct effects of the flood of October 2014 in athens. Bull. Geol. Soc. Greece 2016, 50, 681-690. [CrossRef]

66. Tkachenko, N.; Jarvis, S.; Procter, R. Predicting floods with Flickr tags. PLoS ONE 2017, 12, e0172870. [CrossRef] [PubMed]

67. Annis, A.; Nardi, F. Integrating VGI and 2D hydraulic models into a data assimilation framework for real time flood forecasting and mapping. Geo Spat. Inf. Sci. 2019, 22, 223-236. [CrossRef] 
68. Schnebele, E.; Cervone, G.; Waters, N. Road assessment after flood events using non-authoritative data. Nat. Hazards Earth Syst. Sci. 2014, 14, 1007-1015. [CrossRef]

69. Pennington, C.; Freeborough, K.; Dashwood, C.; Dijkstra, T.; Lawrie, K. The National Landslide Database of Great Britain: Acquisition, communication and the role of social media. Geomorphology 2015, 249, 44-51. [CrossRef]

70. Molini, L.; Parodi, A.; Siccardi, F. Dealing with uncertainty: An analysis of the severe weather events over Italy in 2006. Nat. Hazards Earth Syst. Sci. 2009, 9, 1775-1786. [CrossRef]

71. Molini, L.; Parodi, A.; Rebora, N.; Craig, G.C. Classifying severe rainfall events over Italy by hydrometeorological and dynamical criteria. Q. J. R. Meteorol. Soc. 2011, 137, 148-154. [CrossRef]

72. Meyer, G.A.; Wells, S.G. Fire-Related Sedimentation Events on Alluvial Fans, Yellowstone National Park, U.S.A. SEPM J. Sediment. Res. 1997, 67, 776-791.

73. Neris, J.; Tejedor, M.; Fuentes, J.; Jiménez, C. Infiltration, runoff and soil loss in Andisols affected by forest fire (Canary Islands, Spain). Hydrol. Process. 2013, 27, 2814-2824. [CrossRef]

74. Gariano, S.L.; Brunetti, M.T.; Iovine, G.; Melillo, M.; Peruccacci, S.; Terranova, O.; Vennari, C.; Guzzetti, F. Calibration and validation of rainfall thresholds for shallow landslide forecasting in Sicily, southern Italy. Geomorphology 2015, 228, 653-665. [CrossRef]

75. Staley, D.M.; Kean, J.W.; Cannon, S.H.; Schmidt, K.M.; Laber, J.L. Objective definition of rainfall intensity-duration thresholds for the initiation of post-fire debris flows in southern California. Landslides 2013, 10, 547-562. [CrossRef]

76. Bhat, G.S.; Kumar, S. Vertical structure of cumulonimbus towers and intense convective clouds over the South Asian region during the summer monsoon season. J. Geophys. Res. Atmos. 2015, 120, 1710-1722. [CrossRef]

77. McCann, D.W. The Enhanced-V: A Satellite Observable Severe Storm Signature. Mon. Weather Rev. 1983, 111, 887-894. [CrossRef]

78. Lee, K.-O.; Flamant, C.; Ducrocq, V.; Duffourg, F.; Fourrié, N.; Davolio, S. Convective initiation and maintenance processes of two back-building mesoscale convective systems leading to heavy precipitation events in Southern Italy during HyMeX IOP 13. Q. J. R. Meteorol. Soc. 2016, 142, 2623-2635. [CrossRef]

79. Federico, S.; Torcasio, R.C.; Avolio, E.; Caumont, O.; Montopoli, M.; Baldini, L.; Vulpiani, G.; Dietrich, S. The impact of lightning and radar reflectivity factor data assimilation on the very short-term rainfall forecasts of RAMS@ISAC: Application to two case studies in Italy. Nat. Hazards Earth Syst. Sci. 2019, 19, 1839-1864. [CrossRef]

80. Del Moral, A.; Rigo, T.; Llasat, M.C. A radar-based centroid tracking algorithm for severe weather surveillance: Identifying split/merge processes in convective systems. Atmos. Res. 2018, 213, 110-120. [CrossRef] 